\title{
Var Anglerne Tyskere?
}

Af cand. mag. Gudmund S chütte.

\section{Indledning.}

Aaret 1900 har den særlige Betydning for det sønderjyske Spørgsmaal, at det slutter Halvhundredeaarstiden for den første slesvigske Strid; fra alle Sider stiger Minderne frem af Graven og kræver deres Ret. I hin Strid spillede Spørgsmaalet „Angels og Anglernes Tyskhed“ en Hovedrolle. Nu er Angel tysk, Sprogstriden er trukket nord- og vesterpaa, og der er blevet stille om Anglernes Navn. Kun af og til blusser Striden op i lærde Afhandlinger og Tidsskrifter, og svage Genskin naar ud til det store Publikum, der ser paa disse med en lignende Interesse, som den, hvormed det modtager Meddelelser om Indianere eller Islændere. Som et saadant Genskin vilde - hvis den fik Lov dertil - den Fremstilling af Anglerspørgsmaalet blive staaende, der gives af Professor Joh. Steenstrup i Danmarks Riges Historie I, den vilde som enhver anden Del af vor Historieforsknings Jubilæumsskrift gaa ind $i$ den folkelig-historiske Bevidsthed, men kun forsaavidt denne Bevidsthed overhovedet optager Ting, der ikke blot i Tid og Sted, men ogsaa i national 
Betydning ligger os fjærnt. Det saa meget mere, som Prof. Steenstrups Fremstilling i og for sig kun kan tjene til at gøre os Anglerspørgsmaalet endnu fjærnere, end det i Forvejen var, idet han gør det til et specielt tysk Spørgsmaal, der kun ved ren Misforstaaelse har faaet med Jylland at gøre, saa at dets hele Interesse for os altsaa indskrænker sig til den, som Afsløringen af ethvert lærd Gætværk og Fantasteri har i Videnskabens Historie. Men, skønt Professor Steenstrup saaledes vil slaa en Pæl gennem Anglerspøgelset, har han dog foreløbig først maattet mane det frem; han har ved at behandle det i selve den danske Histories Jubilæumsskrift givet det Interesse for Menigmand, og han maa derfor finde sig $i$, at andre holder det fast og søger at kogle endnu mere Liv i det, inden det nye Aarhundredes Aar et ringer ind.

Lad mig forudskikke et Par almindelige Bemærkninger om Amnets og Behandlingsmaadens Art. Spørgsmaalet om Anglerne i deres Hjemstavn er ikke noget egentlig historisk, thi Anglernes Historie begynder først med og navnlig efter Udvandringen fi'a Hjemmet. Spgrgsmaalet falder ind under E thnologien, et Grænseomraade mellem Historie og Sprogvidenskab, ${ }^{1}$ ) der søger at give et Billede af Folkenes Liv i den ældste Tid, idet den sammenføjer de spredte Vidnesbyrd, der kan hentes fra

1) Man maa enilelig ikke forvixlo Ethnologien med Eth nografien, der heliandler historiske og oftest nulevende Barbarfulka Liv og Kultur. Man kunde maaske for at hruge et dansk Ord sige" "()delslare", idet ()del skulde betegne det gam le folkelin' Arveeje, som or Fithnologiens Horedstof moduat den mere aktuelle Fthnourati. 
historiske Brudstykker, Sagnoverlevering, geografiske 0ptegnelser og kulturel-sproglig Sammenlionning. Det ligger nu i Sagens Natur, at et saadant Stof paabyder den største Forsigtighed, fordi en saa vasentlig Del deraf er Sagn og Rekonstrultion, og fordi der savnes den faste Kontrol, som Historien har i sin Kildekritik. Den historiske Kildekritiks Opgave er at følge den enkelte Beretning gennem alle Kilder, sammenligne deres Varianter, udregne, om Kilden A er afledet af Kilden B eller omvendt, eller om begge afledes af $\mathrm{C}$, eller om $\mathrm{A}$ afledes af $\mathrm{C}$ og $B$ af $D$ osv. Ethnolngien er af gode Grunde fri for denne Kritik, thi de Beretninger, hvorpaa den bygger, gaar yderst sjolden gennem flere historiske Kilder; dens Hovedstof er jo ikke som i Historien Begivenheder, men Tilstande, den behandler ikke Dramaet selv, kun dets Skueplads, Personliste etc., - lutter Ting, der ikke paa den Maade væklier Opmærksombed, at de overleveres fra den ene Kilde til den anden og giver faste Holdepunkter for en systematisk Kritik. Det er overhovedet et Spørgsnaal, om der kan tænkes en systematisk ethnologisk Kritik, en særlig ethnologisk Skole. Der har været nok af Folk, der har kaldt sig Ethnolnger og talt vidt og bredt om ethnologiske Videnskab og Skole, men det har nærmest været Skole i Fantasteri. Foreløbig er der positivt kun at sige, at Ethnologen maa være paa en Gang Historiker og Sprogmand, men især det sidste; thi den sproglige og den dermed forbundne kulturelle Sammenligning er og bliver Tyngdepunktet i Ethnologien. Udover den sproglighistoriske Skole bliver der ingen anden Rettesnor end hver enkelts sunde Fornuft.

Trods denne Mangel paa ethnologisk Skole og trods 
det Vanry, hvori Fantasteriet har bragt Ethnologien, kan man ikke desto mindre tale om en vis Udvikling indenfor dette Fagomraade. Det første Stadium er $\mathrm{Umid}$ de lb a rhedens Tid, da man ganske naivt troede paa alle gamle Beretninger om Folkeslagene og hvilkesomhelst Kombinationer deraf. Den Tid, hvis Historikere tog Romulus, Remus og Ulvinden for gode Varer, faldt det ikke ind at tvivle paa Romerfolkets ethnologiske Udledning fra Troja. Denne Tid troede paa den keltiske og gotiske Folkeoverlevering hos Livius og Jordanes, hvorefter Kelter og Goter var komne til Sydøsteuropa og Lilleasien fra Nordvesteuropa (henholdsvis Frankrig og Sverig), og den troede ligesaafuldt paa lærde Kombinationer f. Ex. den hos Jordanes, der gør Goterne til Oldtidens Geter paa Balvkanhalvøen, eller Middelalderens Forestilling, at Danerne var Geternes Brødre Dakerne. Den Slags Forestillinger levede uforstyrret videre Aarhundreder igennem, indtil de en skønne Dag saa sig stillet for den Domstol, der rejstes af den kritiske Videnskab. Dette Revolutionens Barn, hvis Ubønhørlighed fældede saa mange gode gamle Historiehelte ligefra Romulus til Vilhelm Tell, fik ogsaa sit særlige Virkefeldt indenfor Ethnologien. Daner og Goter mistede deres Forfædre Dakerne og Geterne; Oprindelses-Sagnene hos Livius og Jordanes forkastedes som lærd Opspind, thi Vandringen fra Nordvest til Sydøst, fra Europa til Asien, stred mod den sammenlignende Sprogvidenskabs Resultat, at alle Japhets Sønner, ogsaa Kelter og Goter, var komne fra Asien til Europa, fra Sydøst til Nordvest. Saaledes kunde vort Aarhundredes stringente Forskning flere tusende Aar efter Begivenhederne rette Fremstillingen hos Forfattere, der kun var skilte fra 
Begivenhederne ved faa Sekler. - Men endnu inden Aarhundredets Udløb indtraadte der en Strømkæntring. Der begyndte en Periode, som man kan kalde den kritiske Reaktion og Resignation. Man indsaa, at de kritiske Resultater mangen Gang havde været noget overilede, at Kritiken ganske vist havde været berettiget, hvor den vendte sig mod ældre Lærdes K o m bi nati on er (Daner, Goter = Daker, Geter), men at den ofte havde skudt over Maalet, hvor den vendte sig mod de gamle Folkeoverleveringer (f. Ex. om Kelternes Udvandring fra Frankrig, Goternes fra Østersøegnene) og at de nye Kombinationer, udfra hvilke man kritiserede, ofte ikke var bedre begrundede end de gamle, som man regnede for overvundne Børnesygdomme. (F. Ex. har det vist sig, at "Resultatet" med Japhetsønnernes Urhjem i Asien svæver i Luften, og altsaa ikke kan bruges som Modargument mod Kelternes og Goternes Tog fra Europa til Asien.) Men som det gaar, er der altid nogle, der svinger fra den ene Yderlighed til den anden, og fra at ville vide alting bedre end de gamle Overleveringer er adskillige gennem den kritiske Resignation nu naaede til at ville kritisk bevise Rigtigheden af alt, hvad der staar $i$ de gamle Orerleveringer, og at ville læse alt for meget $u d$ af dem. Men det gælder om at værge Forskningens virkelige Hxjdepunkt, den kritiske Resignation, baade mod den Retning, der vil forkaste alting, og mod den Retning, der vil bevise alting.

Efter disse Forbemærkninger gaar vi over til vort særlige Amne, Anglerspørgsmaalet. Det begynder med - den ældgamle Beretning hos Anglernes Historiker Beda ( $\dagger$ 735), at Anglerne kom fra det sønderjyske Angel. 
Denne Sætning stod naturligvis ved Magt $\mathbf{i}$ den historiske Umiddelbarheds Tidsrum, d. v. s. et fuldt Aartusende. Man søgte ogsaa at give videnskabelige Støttegiunde; tyske Professorer i det 18de Aarh. samlede Sprogprøver fra Angel og søgte deri at finde Ligheder med Engelsk, hvorved deres lykkelige Uvidenhed om, at Angelbomaalet var en god dansk Dialekt, kom dem fortrinlig til Gode.

Saa kom den kritiske Periode, der overfor de gamle ethnologiske Overleveringer udstedte den skaanselsløse Parole: lærd Gætværk og Opspind. Det var en Selvfølge, at Bedas Angler fra Angel maatte dele Skæbne med Livius' Kelter og Jordanes' Goter. Men alligevel slap de naadigere, thi Dødsdommen var ikkke enstemmig; tværtimod fandt Bedas Anglerfortælling de mest glødende Forsvarere i en Del af den nye Tids Lserde. Hvad var det da for en Inkonsekvensens Aand, der foer i disse ellers saa strænge Herrer og bragte dem til at se igennem Fingre paa dette ene Punkt? Selvfølgelig var det ikke Videnskabens Aand, det var Lidenskaben, det var Politiken. Her møder vi en Faktor, som vi ikke har kunnet medtage i den almindelige Oversigt over Ethnologiens Historie; det er denne nye Faktor, der har gjort Anglerspørgsmaalet saa særlig interessant og saa forkludret. Den tyske Nationalitetspolitik fandt Bedas Anglerfortælling formaalstjenlig, derfor nænnede den ikke at maale den med samme Alen som Livius og Jordanes; omvendt var det naturligvis heller ikke videnskabelige Hensyn af det reneste Vand, der her gjorde os Danske saa ivrige for at dømme efter den nye Lovs allerstrængeste Bogstav. Under disse Forhold udartede den videnskabelige Diskussion hurtig til den rene Parodi, til slet og ret politisk Spilfægteri. Man 
flyttede bare den moderne politiske Holmgang tusende Aar tilbage i Tiden, gav det nye et gammelt Skilt, det var det hele. Man talte om Uffe hin Spage og hans Modstandere, Saxerne paa Eiderholmen, og man tænkte paa Eiderdanismen og Slesvigholsteinismen. Pudsigt nok var det imidlertid, at Danske ogr Tyske, trods Uenighed om Sagen i alt muligt andet, mødtes i den skønneste Enighed paa et Punkt, nemlig den Forudsætning, - at Anglerne var Tyskere. Naturligvis var Konklusionen - den politiske Benyttelse - helt forskellig. De Danske hævdede: da Anglerne var tyske, og Angel fra Arilds Tid havde været dansk, kunde Anglerne aldrig have boet i Angel. Tyskerne hævdede: da Anglerne var tyske og fra Arilds Tid havde boet i Angel, kunde Angel aldrig have været dansk.

Men som sagt, Forudsætningen, Anglernes Tyskhed, var man enig om, og det var besynderligt nok, thi da det hele for de flestes Vedkommende intet havde med Videnskab at gøre, men var den rene og skære Politik, kunde vi Danske akkurat ligesaagodt have hævdet den stik modsatte Position og annekteret Anglerne som gode Danske: hos Saxe er jo Angel Broder til Dan. Der var ogsaa en Mand, der gjorde dette, og det en Mand, der ikke var saadan at foragte, nemlig Grundtvig, - ham kunde man vel paa det Punkt nok kalde en videnskabelig Autoritet, eftersom det er ham, der ved Siden af Rask har bidraget mest til at grundlægge Studiet af Oldengelsk ikke blot herhjemme, men ogsaa i selve England. Men hans Røst blev en Røst i ørkenen. Vi lod os gaa paa af Tyskerne, vi opgav i vort Hjærtes Enfoldighed den gode Position at hævde Anglerne som danske, vi udleverede 
dem uden et Sværdslag til Tyskerne og paatog os saa heltemodig den fortvivlet utaknemmelige Opgave at forsware Eidergræensen mod disse "tyske“ Angler.

Da nu Tyskerne havde sikret sig Stridens Genstand, Angel med hele Sønderjylland i Tilgift, tabte deres Videnskabsmænd hurtig Interessen for at bevise Anglernes Tyskhed. „Der Mohr hat seine Schuldigkeit gethan“, og han har faaet Lov at gaa. Nuomstunder er der næppe nogen anstændig tysk Videnskabsmand, der kalder Engelsk for tysk; man nøjes med at stille det sammen med Tysk til en snævrere Gruppe, Vestgermansk, modsat Nordgermansk (Nordisk) og Østgermansk (Gotisk etc.). Anglernes Hjemstavn tænker man sig stadig nærmest i Angel, men uden at lægge nogen særlig Vægt derpaa. Den kritiske Resignation er indtraadt. Vel at mærke, dette gælder kun for den anstændige, virkelige tyske Videnskab, ikke for den „Videnskab“, som den preussiske Politik holder det for sundt at byde det store Folk. Dér er Englænderne stadig tyske Angelboer og den jyske Dialekt „nedertysk-germansk“ (jfr. Filskow, s. „Sdj. Aarb. “ 1899, S. 116), dér bankes det ind $\mathrm{i}$ Børnenes Hjærner af den kgl. preuss. autoriserede Almuegeografi (187de Opl.), at Danmark er et „tysk Aussenland“, Jylland en "nordtysk Halvø“ osv.

I Danmark er Forholdene noget anderledes. Den umiddelbare Anledning til politisk Interesse i Anglerspørgsmaalet er bortfalden, idet Angel er bleven fortysket, og den tyske Videnskab har opgivet AnnexionsPolitiken. Den tyske Populærfremstillings Fortsættelse af Annexionspolitiken byder naturligvis nogen Anledning til fremdeles at være paa Post, men de stortyske Skriverier er for lidt kendte til at ændses, skønt de forresten 
netop i den sidste Tid har taget saa stærk Fart i den saakaldte "altyske" Bevægelse, at der nok kunde være Grund til at raabe Vagt i Gevær. Forsaavidt altsaa Interessen for Spørgsmaalet ikke er sovet helt ind, kan man paa en Maade sige, at den er kommen tilbage $i$ den rolige Gænge, hvori den vilde have udviklet sig, dersom den hele politiske Larm og Forkludring ikke havde været til. Grumset har bundfældet sig, og man kan nu iagttage den ethnologiske Opfattelses tre Udviklingslag tydelig og klart ved Siden af hinanden. Det umiddelbare, naive Trin repræsenteres af det brede Lag. Kanske hænger der hist og her noget af den lærde Mistænkeliggørelse fast, der i Kampaarene blev udspredt imod gamle Berla, men for det meste er det vist glemt, og er den folkelige Opfattelse overladt til sig selv, vil den selvfølgelig nu som altid tage Bedas Angelboer og Jyder efter Bogstaven. Hertil kommer det umiddelbare Sprograisonnement, som siger: „Engelsk er jo næsten ét og samme Sprog som Jysk. “ Endelig støttes den umiddelbare Opfattelse ved Grundtvigs folkelige Autoritet og Folkehøjskolens Populærvidenskab.

Den strænge Kritik overfor den gamle Overlevering og overfor den umiddelbare Opfattelse repræsenteres af danske Historikere som Joh. Steenstrup og Kr. Erslev' ${ }^{1}$ ) og endvidere af Svenskeren Erdmann. ${ }^{2}$ ) De lader sig ikke beherske af dot overfladiske Indtryk fra Nutidsengelskens Iighed med Nutidsjysk; de gaar til Oldsprogene og hævder her stadig, at Engelsk afgjort er et tysk Sprog, og de bruger denne Opfattelse som Modbevis

1) Jfr. Art. "Angler", Salom. Konv. Lex. ") Ueber die Heimat und den Namen der Angeln. Upsala 1890-91. 
mod Bedas Ord om Anglernes Hjem i Angel. Maaske er de ikke altid fri for et Stænk af Bitterheden fra hampaarene, men det maa erkendes, at de i Hovedsagen dømmer ud fia virkelig saglige Overvejelser. Edruelig er navnlig Erdmann, der imod Beda den ærværdige fører en endnu ældre Autoritet i Marken, nemlig Ptolemæus, den klassiske Geograf, som levede 5-600 Aar for Beda og sætter Anglerne dybt inde i Mellemtyskland. - Endelig kommer vi til den kritiske Resignation; den repræsenteres af vore Sprogmand. De kan ikke godkende Grurdlaget for Historikernes Kritik af den folkelige Overlevering og Opfattelse. Er det urigtigt at dømme det 5te Aarhundredes Engelsk og Jysk uả fra det 19de Aarhundredes, saa er det ikke stort bedre at dømme det ud fra det 8., 9. eller 10. Aarhundredes Oldengelsk og Oldnordisk. Men selv det sadvanlig foreliggende Oldengelsk berettiger ikke til Benævnelsen "tysk“; naar selv de tyske Sprogmænd nuomstunder har opgivet den, burde vore Historikere ikke haardnakket fastholde den. Engelsk kan kun stilles sammen med Tysk til en snævrere Gruppe, som vore Spprogmænd dels ligesom de tyske kalder "vestgermansk", dels, ganske inkonsekvent, slet og ret „germansk“. Vore Sprogmænd gør saledes dobbelt Front, dels mod den folkelige Opfattelse, Engelsk = Dansk, dels $\bmod$ Historikernes Engel:k = Tysk; de mødes med de tyske Sprogma nd paa et forsigtigere Mellemstandpunkt, og, hvad Hjemstavns-Spørgsmaalet angaar, er Folgen den, at de iklse længer afgjort tør bestride Rigtigheden af Bedas Ord om Anglernes Hjem i Angel. Enkelte (som Herman Møller og Axel Olrik) er enilog stærkt tilbøjelige til at give Beda Ret overfor Ptolemæus. 


\section{Kritik af de aldre Opfattelser af Anglernes Kultur og Sprog.}

Et Hovedkrav til videnskabelig Undersøgelse er, at enhver 'Tilstand skal bedømmes udfra sine egne Forudsæetninger i Tid og Sted. Man maa undgaa Foregribelse af senere Udviklingstrin og Overforelse af Forestillinger fra uvedkommende Forhold. Billedlig udtrykt: man bør ikke hænge en Mand i hans 20de Aar for noget, han før:t har begaaet $i$ sit 30te, eller for noget, som en helt anden har hegaaet.

Dette Hovedlkrav har alle hidtidige Opfattelser af Angler.pnrgsmaalet tilsidesat, mere eller mindre. Den naive, umiddelbare Opfattelse aner slet ikke Kravets Tilværelse, den unge videnskabelige Kritik rejser Kravet, men har naturligvis, saałænge den staar paa bar Bund, grumme ondt ved at friggre sig for den menneskelige 'Tilbojjelighed til at se Fortid gennem Nutids Briller. Og er det smaat med Ernen, selv hvor Viljen er god, bliver det selvfolgelig rent galt, hvor i Virkeligheden Viljen mangler. Men det var netop Tilfaldet ved Anglersprrgsmaalet af de ovennæunte politiske Grunde. Der var omtrent iklke én, der brød sig om de virkelige gamle Angler og Jyder, deres Sprog og Kultur. Tyskerne brøil sig nærmest kun om det specielt tyske, der kunde paavises hos Anglerne og i Angel med Tillæg af Jylland og hele Danmak. Danskerne brød sig slet ikke om Anglerne, - fordi de var tyske -, og eller's absolut kun om det specielt danske, der kunde paavises i Angel osv. Og disse "Paavisninger" tog man, livor man kunde bedst. 
Da det kun var smaat med Materialet $\mathbf{f} ø \mathbf{r}$ Anglernes Udvandring, tog man ganske rolig, hvad der kom bagefter, — selv det tyndeste $\emptyset 1$.

Den stadige Adresse til Nutidens politiske Forhold gjorde, at der ikke blev øvet den tilstrækkelige Censur; Foregribelser og vilkaarlige Overførelser løb hvert Øjeblik med, naar de blot var politisk formaalstjenlige. Herom var Tyske og Danske omtrent ligegode; Forskellen laa nærmest blot i Maaden. Tyskerne bryggede løst og fast sammen med en ustyrlig Fantasi og en Elasticitet, der ikke skyede at annektere specielt nordisk Stof, naar man dermed kunde stoppe Hullerne $i$ den gamle tyske Overlevering. Danskerne raisonnerede med Noget, der skulde gælde for Adruelighed, men som i Virkeligheden var Snæversyn, man lavede sig et Sneglehus, som man kaldte „ægte dansk-nordisk“, men som i Virkeligheden var ligesaa forlorent som den daværende Edruelighed overhovedet. - I det følgende skal vi nøjere belyse det her sagte.

A. Anglernes nærmere Omgivelser og deres Kult ur. Grundlæggelsen af den moderne Kulturhistorie og den sammenlignende Sprogvidenskab maatte have til næsten naturnødvendig Følge, at man ikke med god videnskabelig Samvittighed kunde isolere et Spørgsmaal som det om Anglerne. Hvis man vilde fyldestgøre Kravet om at dømme Tilstandene ud fra deres egne Forudsætninger, maatte man nødvendigvis undersøge hele det sproglige og kulturelle Niveau til begge Sider. Det var Tyskerne, der tog dette Krav op, ligesom det var dem, der overhovedet stadig havde vor Folkeklasses Helhed og Enhed for Øje; vi Danske lod det $i$ vort stoknordiske Snæversyn ligge. 
1. Den tyske 0 p fattelse. - Materialet til Oplysning om Urkulturen i Anglernes Nabolande er meget ringe. Den hjemlige Overlevering begynder forst flere Aarhundreder efter Anglernes Udvandring; af samtidige Vidnesbyrd har vi kun nogle ganske faa spredte i romerske Kilder, for Resten er vi overladte til Kombinationer mellem disse og de Levninger af Urtilstandene, der har reddet sig ned til senere Tider, navnlig i den nordiske Overlevering. Nu fandt Tyskerne Spor af en stærk Indvandring af tysk og anden sydgermansk Kultur til Norden; ofte er det sydlige Stof alene bevaret $i$ den nordiske Overlevering. Saaledes er Niflungesagnets Stof burgundisk, selve Overguden Odins Dyrkelse angives hos Snorre udtrykkelig som. indvandret sønclenfra. Men særlig mange af de nordiske Gude- og Sagnfigurer genfindes hos Angelsaxerne, saaledes Gaut (Odin), Hermod, Njord, Ingve-Frey, Kong Skjold med Neget, Skjoldungerne, Vermund-Uffe, Frøvin-Vig, Retsguden Forsete paa Helgoland (Forsetesland); ja enkelte Sagnfigurer fra Danmark og dets Omgivelser el os kun bevarede netop hos Angelsaxerne, saaledes Beovulf, Huglek, en Danekonge Alevih etc. Man sluttede nu, at disse Frllesfigurer, der mest hører hjemme i det danske Rigsomraade, er Udtryk for en Kultur, der gik forud for den egentlig nordiske. En ganske særlig Rolle herindenfor spiller Heroen Ingve. Efter det germanske Ophavssagn hos Tacitus, Germania, Kap. 2, er han en af Urmennesket Mannus' tre Sønner, og som hans Efterkommere "Ingveones" betegnes Stammerne ved Kysten. Plinius (Historia naturalis, Kap. 96) nævner som derhen hørende: Chauker i Hannover og Kimbrer i Jylland (den kimbriske Halvø), d. v. s. Angelsaxernes Naboer til begge Sider; man regner derfor ogsaa 
Ancrelsaxerne selv til Ingves Sønner, idet man søger en videre Støtte derfor i Tacitus' Skildring af deres Gudsdyrkelse og i en Kombination med den nordiske Overlevering. Tacitus skildrer i Kap. 40, hvorledes Anglerne sammen med Varner og andre Nabostammer dyrker en Fredens og Frugtbarhedens Gudinde paa en $\emptyset$ i Havet. Hendes Navn læstes først Hertha, og hendes $\varnothing$ opfattedes som Sjælland, hvor man fandt en "Herthadal" (i Virkeligheden "Artedal“). ${ }^{1}$ ) Senere opdagede man, at Navnet skal læses Nerthus, hvilket er den nøjagtige Grundform til det nordiske Navn Njord. Og denne Gud, Fredens og Frugtbarhedens Giver, svarer nøjagtig til Tacitus' Nerthus, ene paa Kønnet nær; de opfattes derfor som et Søskendepar svarende til Frey og Freyja. Njordsdyrkelsen folyes imidlertid altid med Dyrkelsen af Ingve-Frey; dennes ivrigste Dyrkere, den svenske Kongeæt Skilvinger, kaldes Ynglinger (egtl. Inglinger) eller Inguner, der svarer tıl det engelske Ing-vine („Ingvenner"), som tillregres de danske Skjoldunger. Den her paaviste Forbindelse meliem Ingve og Njord bestyrker Sandsynligheden for, at vi virkelig har Ingve-Sønner for os i de Stammer, som dyrker Nerthus, og som allerede efter de geografiske Opgivelser hos Tacitus og Plinius maatte henregnes til Ingve-Sønnerne. Dette Navn opfattes derfor som en Slags Religionsbetegnelse for Nerthuseller Njords-Dyrkelsen; dennes Forherligelse af Fred og Frugtbarherd genfinder man i den engelsk-danske SkjoldsMythe og i den danske Balder's-Mythe. Ingve-Religionens Hovedsæde fanilt man i de frugtbare danske Øer; jfr. den oldengelske Rune-ABC's Ord „Iny var først hos Øst-

1) Jfr. (1)rik, Art. "Hertha“ i Salm. Konv. Lex. 
danerne" ${ }^{1}$ ). Derimod de virkelige Skandinaver deltog ikke. De Folkestammer, som efter Tacitus' Ord deltager i Nerthus-Dyrkelsen, og som paa Anglerne nær var ganske husvilde $i$ den gamle Geografi, anbragte man rundt om $i$ Danmark (f. Ex. Anglernes Naboer Varnerne genfandt Müllenhoff i Landsbyen Varnæs ved Aabenraa Fjord, altsaa nærved Angel). Ogsaa i Bebyggelsesformen paaviste man ingveonsk Kulturfællesskab igennem Stednavnetyper som den paa - lev (Haderslev), der strækker sig over hele Danmark med Skaane og Halland og genfindes netop i de Egne af Tyskland, hvor Ptolemæus sætter Anglerne (som -leve, -leben: Eisleben) Disse Navnetyper, der stadig ligesom taler Urbefolkningens Sprog, tillader endnu i vor Tid at afgrænse det ingveonske Omraade mod det skandinaviske med stor Nøjagtighed. Endelig er der jo det endnu levende Sprogs Vidnesbyrd, idet jo det halve Jylland den Dag idag taler en Dialekt, der paa tysk-engelsk Vis sætter den bestemte Artikel foran Hovedordet: „e Mand“, ikke som i det rigtige Nordisk bagefter: „Manden“.

Saavidt den tyske Opfattelse. Og det var ikke blot i Principet, at den var inde paa den rette Vej, mange af de opstillede Enkeltheder er faktisk sandsynlige eller rigtige. Hele Antagelsen af en særlig ingveonsk Kultur er, om ikke bevist, saa dog heller ikke modbevist, og der er meget, der taler for den. (Jfr. Ax. Olrik i Salom. Konvers. Lex., Artik. „Daner" og "Ingve".) Den tyske Stofindvandring til Norden staar nuomstunder som ubestridt Kendsgerning, saaledes ved Niflungesagnet, ved

1) Ingves Navn betegnede $i$ det ældste Runealfabet (F upark'en) Rumen ng. Navnet findes anvendt ogsaa i Goternes Alfalet. 
Odinsdyrkelsen etc. (Jfr. Henry Petersen, Om Nordboernes Gudetro).

Men i Benyttelsen af denne Kendsgærning var Tyskerne unægtelig lovlig dristige; den bød dem et Operationsfelt for Foregribelser, vilkaarlige Overførelser og Annexioner i stor Stil. Det er bekendt nok, hvorledes det lykkedes Tyskerne i Kraft af den tyske Stofindvandring at gøre omtrent hele den nordiske Mythologi, de alleryngste Skjaldeprodukter indbefattet, til tysk Urejendom. Mindre bekendt, men ligesaa betegnende er deres Maade at stedfæste Ingveon-Kulturen paa. Den kaldes tysk, den er Særeje for Englændere og Friser, Skandinaverne er udelukkede, og den sidste Sætning bruger Kögel (Deutsche Literaturgesch. I. 157, Anm. 1894) atter som Bevis for, at Beovulfskvadets Daner ikke var Skandinaver, thi disse Daner kaldes Ingveoner (Ingves Venner), altsaa Tyskere.

Hvilken Hjemmel giver nu Kilderne til at regne f. Ex. Friserne til Ingves Sønner'? Absolut ingen. ${ }^{1}$ ) Den eneste Anledning til Medtugelsen er den Kendsgærning, at Friserne staar Englænderne sproglig nærmest. Den sproglige Gruppe Anglo-Friser har man da udenvidere slaaet sammen med den kulturelle Gruppe Ingve-Sønnerne.

Omvendt: hvilken Hjemmel giver Kilderne til at udelukke Skandinaverne? Absolut ingen. Det strider direkte mod Plinius (Hist. natur. IV. 96), der omtaler Ingveoner i det nordlige Skandinavien, og mod de senere nordiske Over-

1) Det eneste skulde være det med Nordboer nes fielles Gudenavn Forsete, men det er et stort Spørgsmaal, om Forsete dyrkedes i Frisernes egentlige Hjemstarn (Holland); hans Dyrkelse er kun paaviselig paa Helgoland eller Forsetesland, hvor Friserne ikke oprindelig har hjemme, men er indvandrede under Folkevandringen eller senere. 
leveringer; der viser Hovedsædet for Ingve-Freys og Njords Dyrkelse $\mathrm{i}$ det svenske Upland. Den eneste Anledning til Udelukkelsen er den Kendsgærning, at Nordboernes Sprog ikke slutter sig saa nær til Englændernes, som Frisernes gør. Altsaa for sprogligt Konselvensmageris Skyld overfører og udelukker man stik imod Kildernes og de kulturelle Kendsgærningers Vidnesbyrd. Ligesaa vilkarlig er Stedfæstelsen for de enkelte Ingveon-Stammer ved Hjælp af Stednavne-Etymologier, f. Ex. Varnerne i det nordslesvigske Varnæs. Man forstaar ikke, hvorfor Tyskerne ikke har gjort Skridtet fuldt ud ved at forfølge Varnerne over Var-de i Vestjylland og Var-berg i Halland til Var-dø-hus ved Nordkap, hvor de antagelig har fundet deres Endeligt og sidste Hvilested. Saa er der Endelsen -lev; at den er fordansk-ingveonsk, er dog ikke bevist, fordi man finder en Hob Navne paa - lev nede i Mellemtyskland, i Nerheden at nogle Angler og Varner. Naar Tyskere skulde kunne komme fra Danmark til disse Egne og bringe -lev-Navnene med, hvorfor skulde saa ikke Danskere kunne gøre det? Rentud parodisk er Konfusionen i en Afhandling af Seelmann (Niederdeutsche Jahrbücher XII, 1886), der paaviser, at -lev-Navnene tilhører Varnerne, medens deres Brødre Anglerne ingen Del har i dem. Seelmann finder en Støtte for sin Opdagelse deri, at -lev-Navnene hører op nøjagtig ved Angels Grænse, med Villabyen Waschersleben ved Bunden af Flensborg Fjord. Og hvorfia stammer saa i Virkeligheden dette "urgermanske“ Navn" Fra en gammel varnisk Høvding Wascher paa Folkevandringens Tid? Nej fra en kongelig dansk Konferensraad Waschersleben i Slutningen af forrige Aarhundrede. Han havde en Villa 
paa Stedet dér, som paa borgerligt Dansk hed og hedder "Sosti“ ; nu plejede Flensborgerne at gaa sig en Tur derud, og saa sagde de "ud til Wascherslebens", og tilsidst beholdt Stedet dette Navn istedenfor det grimme danske Sosti. NB. kun i Flensborgernes Sprog og paa de tyske Kort; havde derfor Seelmann holdt sig fra de tyske Kort med deres nye og fortyskede Navne, var han som god Filolog gaaet til den ældre Overlevering, d. e. de danske Kort, da havde han sparet sig denne Fejltagelse, der jo unægtelig sætter Rekorden i Retning af Foregribelser.

2. Den danske Opfattelse. I Tyskernes Argumentation havde der for en fornuftig Kritik været nok at tage fat paa baade af godt $0 \mathrm{~g}$ daarligt. Men den danske Kritik lod det ligge. Der var overhovedet ingen virkelig dansk Kritik overfor det tyske Standpunkt af den simple Grund, at det hele Spørgsmaal med de gamle Anglers kulturelle Niveau var Luft for den danske Videnskab. Man stirrede sig blind paa den tyske Overleverings og Opfattelses Forvirring og paa Herligheden og Klarheden i den rige nordiske Overlevering. De tyske Annexionsforsøg gjorde paa den ene Side, at man holdt desto mere skinsygt paa det nordiske, paa den anden Side voldte de, at man hverken vilde eje eller have noget tysk, dels af umiddelbart Nationalhad, dels fordi man ikke vilde lade Skygge af Annexions-Mistanke sidde paa sig. Følgen var, at man intet vilde vide om den romerske Overlevering fra Tiden før Anglernes Udvandring; den var for det forste forvirret, for det andet kaldte den Nordboerne for "Germaner" og var derfor allerede udnyttet af Tyskerne, - det var nok til, at man ikke kunde bruge den. Tacitus' Værk „Germania“ med dets uskattérlige Fond af 
Oplysninger om vor Folkeklasses Urtid, - det kunde Tyskerne skalte med efter Behag, det skulde blive en lukket Bog for os Danske. Man vilde begynde med vor Histories klare Dag, med Gorm den gamle, Jællingestenene, Eddaerne etc., kort sagt, kun med hvad der var ægte og ubestridelig dansk-nordisk. Saaledes troede man at sky Annexionen, og paa samme Tid sad man i den til op over begge Øren. Næsten hele det Apparat af Mythologi, Skjalde etc, hvormed man udstyrede den dansk-nordiske Kultur, var jo i Virkeligheden slet ikke fællesnordisk, endsige dansk, men norsk-islandsk. Det begyndte Nordmændene ogsaa allerede dengang at hævde, men man stoppede haardnakket Ørene. - Afset derfra kunde det snævert nordiske Standpunkt have været godt nok, naar man bare havde overholdt dets Begrænsning. Man skulde have nøjedes med Hærdelsen af, at Danınark fra Historiens Morgen er nordisk i Sprog og Kultur lige ned til Ejderen, - det skulde man have hævdet med Kraft overfor Tyskernes Paastande om Jyllands stadig fortsatte Tyskhed, og samtidig skulde man have indrømmet, at om Tiden $\mathbf{f} ø \mathbf{r}^{\cdot}$ Historiens Morgen siger vore nordiske Kilder os intet. Men til en sardan Erkendelse strakte „AEdrueligheden" ikke til. Det, der var godt Bevis for Danmarks Danskhed omkring Aar 8--900, det skulde med Vold og Magt gælde fra før Syndfloden. Naar Tyskerne talte om Danmarks ingveonske Kultur omkring Aar 500, mødte man op mod Dannevirke-Runestenene fra omkring 900. D. v. s. der raabtes i Øst, og man svarede i Vest. Saaledes bortspillede man i national Forblindelse de gode historiske Kort, man havde paa Haanden, og spærrede for mange Aartier Vejen for en saglig Opfattelse af Danmarks Urtid. 
B. Det sproglige Anglersporgsmaal. Dan $k$ eller Tysk? Ved den videre kulturelle Baggrund maatte vi indrømme, at den tyske Videnskab fra første Færd $i$ Principet respekterede Kravet om at dømme Tilstandene udfra deres egne Forudsætninger, og at den $\mathrm{i}$ den Retning virkelig ydede Noget positivt. Ved det snævre sproglige Anglersporgsmaal larler der sig ikke yde Tyskerne den sanme Ros fremfor Danskerne. Tyske og Danske var her absolut ligegode om at tilsidesætte det videnskabelige Hovedkrav; man overførte om Kap paa Folkevandringstidens Danske, Angler og Tyskere alle vore moderne Forestillinger om Sprog og Nationalitet. Disse kunde ofte $\mathfrak{i}$ tilstrækkelig høj Grad være Vrangforestillinger, hvad selve de moderne Forhold angik; man kan da tirnke sig, hvor godt de kunde passe paa Oldtidsforhold et tusend Aar tilbage i Tiden!

- Det gælder ikke blot Enkeltheder, - det gælder først og fremmest Hovedforudsætningen for den liele Anglerstrid: Spørgsmaalet Dansk eller Tysk. Inden man skred til Diskussionen om, hvorvidt det 5te Aarhundredes Angler var danske eller tyske, havde det dog dog varet paa sin Plads at undersøge, om det 5te Aarhundrede overhovedet kendte Begreberne "Dansk" og "Tysk". Men det sparede man sig. Man gik stadig. ud fra det 19de Aarhundredes Begreber Dansk og Tysk, som var det noget, der havde existeret aller mindst siden Verdens Skabelse. $O g$ dog kunde allerede dencang den sammenlignende Sprogforskning oplyse $\mathrm{om}_{\text {r }}$ at Dansk og Tysk engang havde været ét, og at Forskellen først gradevis havde udviklet sig. Og det var allerede 1852 , at Joh. Schmidt fremsatte sin „Bølge- 
theori“, der angreb den hidtidige Opfattelse af Sprogenes Afstamning og traadte i Skranken for de jævne, umærkelige Overgange, en Theori, som den nyere Tids Resultater kun har kunnet bekræfte. Joh. Schmidt anvendte den specielt paa Overgangen mellem Engelsk og Nordisk og bestred Antagelsẹn af en skarp Nationalitetsgrænse. Ligeledes kunde man allerede 1837 læse paa Prent $i$ vor Folkeklasses ethnologiske Bihel, Zeuss, ${ }^{1}$ ) at Navnene Tysk og Nordisk først dukker op 3-400 Aar efter Anglernes Udvandring, og at det ingen Tilfældighed er: Den ældste Tid kender overhovedet ingen nationale Samlingsnavne, kun Smaastammenavne, som f. Ex. ved Mellem- og Nedrerinen: Sugambrer, Bruchtrer, Tenchtrer, Bataver etc. Folkevandringstiden lader Smaastammenavnene gaa op i større Samlingsnavne, f. Ex. de ovennæunte i Frankerne, andre i Alemannerne, Bajrerne, Thyringerne, Saxerne, men det er først flere Hundrede Aar derefter, at de store nationale Samlingsnavne Tysk, Engelsk, Dansk, Svensk, Norsk opstaar, nemlig ved Grundlæggelsen af Enhedsstater. Samtidig opstaar gennem Vikingetidens krigeriske Samliv Fullesbegrebet Nordisk overfor Engelsk og Tysk.

Den hele Strid, om Anglerne var Danske eller Tyske, er altsaa sproglig betragtet ikke langt fra at være en Strid om Kejserens Skæg. Politisk var den det jo ikke, der var den kun altfor reel, desværre for os, og af den Grund blev den gamle Forskel pustet op til noget stort. Den patriotiske Følelse kunde ikke undvære det tusendaarige Perspektiv, at Danske og Tyske havde raset mod hinanden og sprogplaget hinanden i salig Kong Uffe hin Spages Dage nøjagtig ligesom i Kristian den 8des.

1) Die Deutschen und die Nachbarstämme. 
Til en vis Grad kan man ganske vist nok sige, at Tyskerne allerede i Kampaarene indtog et mere udjævnende Standpunkt, - saamegen Elasticitet var i dem -, men det var rigtignok ogsaa paa en egen Maade. De gik ud fra Romernes Sprogbrug, der kalder hele vor Folkeklasse „Germaner", men dog fortrinsvis bruger Navnet Germaner om de senere tyske Stammer, hvoraf atter Nutiden udleder Betegnelser som "Germanisme" $=$ Tyskeri, "germanisere" = fortyske etc. Udtrykket Germansk havde altsaa paa Forhaand netop den Elasticitet, der passede for den Tendens, som vilde gøre Tyskheden til hele vor Folkeklasses Ophav. Men det var ikke nok. Man helmede ikke, før man fik udvidet selve Navnet "tysk“ til den samme Elasticitet. De egentlige Skandinaver var altsaa Tyske $\mathrm{i}$ videste Forstand, derpaa kommer Øst-Danmarks ingveonske Urindbyggere som Tyske i snævrere Forstand, og endelig Jyder, Angler etc. som Tyske i aller snævreste Forstand. Dette er jo omtrent den Joh. Schmidt'ske Opfattelse med de jæune Overgange og flydende Grænser, og den kunde man jo til Tider ogsaa have Brug for, men j Reglen opfattedes det ikke paa den Maade. I Reglen opfattedes Østdanskerne som oprindelig ligesaa gode Tyskere, som Angler og Jyder er den Dag idag; Østdanskernes Halvtyskhed er en 'Tyskhed, der er undertrykt ved en Denationalisering, som Angler og Jyder endnu har undgaaet, - kort sagt: et tabt Udenværk foran den egentlige Hovedposition. Men, hvad enten man antog en flydende eller fast Grænse mellem Nordisk og Tysk, om en Ting var man enig: at denne Overgang eller Grænse fandtes paa det skandinaviske Fastland og ikke paa det mellemeuropæiske (den jyske Halvø). De gamle Angler 
og Jyder var altsaa under ingen Omstændigheder et Grænsefolk, men et Folk midt inde i Tyskland.

I det folgende skal vi i det enkelte gennemgaa de forskellige Sprogopfattelsers Bevisførelser, men forinden maa vi nøje gøre os klart, hvad det er, det kommer an paa for at fyldestgøre Kravet om at bedømme Tilstandene udfra deres egne Forudsætninger. Vi har ovenfor fastslaaet: det er misligt at kalde Anglerne for Tyskere, thi dengang de boede ved Siden af de senere Tyskere, hed disse endnu ikke Tyskere, og dengang Tyskerne begyndte at kalde sig Tyskere, var Anglerne vandrede udenfor Navnets Rækkevidde, og de har aldrig optaget det.

Den korrekte Form for Spørgsmaalet er denne: stod Folkevandringstidens Engelsk nærmest ved det samtidige Sprog hos de Stammer, der senere kom til at hedde tyske, eller stod det nærmest ved det samtidige Sprog hos de Stammer, der senere kom til at hedde nordiske? Nu er Sprogsammenligning af denne Art en uhyre vanskelig Sag. Sprogene marcherer jo ikke paa Stedet eller avancerer paa Linje og delingsvis som Soldater i Parademarsch. De udvikler sig i spredt Kæde: naar Sproget B -det ene Øjeblik gør højre om med A, gør det i næste Øjeblik venstre om med $\mathrm{C}$; - naar $\mathrm{B}$ i Begyndelsen holder Trit med A og C, gør det i næste Øjeblik Holdt, og i næste Øjeblik igen indhenter og overfløjer det A og C Det er nu let nok at tage Sprogene paa et eller andet Tidspunkt og sige: A og B marcherer i Øst, C i Vest, men hvad i Alverden kommer det os ved, naar vi taler om Situationen paa den foregarende Krigsskueplads? Lad os anskueliggøre det ved en anden Lignelse. Vi skal 
sammenligne tre Personer: A har lange Arme og Ben, lige Næse, flade Øren, blaa Øjne, glat Haar; B har korte Arme og Ben, krum Næse, struttende Øren, sorte Øjne, kruset Haar; $C$ endelig har ingen af Delene, thi han mangler baade Arme og Ben, Næse og Øren, Øjne og Haar. Hvem ligner nu mest A, enten B eller C? Et Barn eller en umiddelbart raisonnerende Person vil sagtens svare: det gør $B$ ! Men enhver, der har Fftertanke, vil sige: vis mig først et $æ$ ldre Billede af $\mathrm{C}$. Han er dog vel næppe født uden alle de nævnte Legemsdele, og naar man fik ham at se $\mathrm{i}$ komplet Tilstand, kunde det jo gærne vare, at han lignede A meget mere, end B gør. Nøjaytig ligesaadan gaar det ved Sprogsammenligningen. I Tidens Løb mister det ene Sprog denne Legemsdel, det andet hin, og det kan meget godt hændes, at to hinanden aldeles fjærntstauende Sprog bevarer én og samme Ejendommelighed, medens deres virkelige Søstersprog opgiver den. Der danner sig paa den Maade rent tilfældige Ligheder og Forskelligheder, der bliver ligesaa mange uundgaaelige Snublebaner for Lægmanden, naar han vover sig ind paa Sprogsammenligningens Glatis. Kun den, der véd at skaffe sig Adgang til det ældste Sprogstades Støtte, kun den gaar nogenlunde sikkert.

Jeg skal søge at illustrere dette ved Exempler fra de forskellige Opfattelser af vort Spørgsmaal.

I. Den umiddelbare Opfattelse. Det er den, der tager Bedas engelske Angelboer og Jyder for gode Varer som virkelige Angelboer og Jyder fra Danmark. I Sproget finder den det bekræftet derved, at Engelsk og Jysk omtrent er et og det samme. Heri mødes den ældre 
tyske Opfattelse med den folkelig danske. Som altid er naturligvis Konklusionen, Benyttelsen, den diametralt modsatte. Tyskerne siger: Jysk er Engelsk, altsaa er det Tysk; Danskerne siger: Engelsk er Jysk, altsaa er det Dansk. $\left.{ }^{1}\right)$ - Men iøvrigt er den sproglige Argumentation aldeles ens. Her nogle Prøver:

a. Jysk har Dobbelt-V ligesom Engelsk, f. Ex. i Wind, Wonsdaw; eng.: wind, modsat nordisk Enkelt-V i Vind, (forresten ogsaa modsat tysk Wind, hvor der vel skrives $\mathrm{W}$, men udtales $\mathrm{V}$ ).

b) Jysk har dette W mange Steder, fælles med Engelsk, hvor Nordisk ikke engang har V, f. Ex. Wonsdaw, eng.: Wednesdag (tysk Woden-), men nordisk Onsdag.

c) Jysk har Sløjfning af Endelsens E ligesom Engelsk: å bind', a rid' = to bind, to rid(e), modsat dansk binde, ride, tysk: binden, reiten.

d) Hele Sætninger lyder ens paa Jysk og paa Engelsk. Sætningen „Jeg behøver en Sax“, tysk: „Ich bedarf einer Scheere", hedder paa Engelsk: „I want a scissor", udtalt „Ai wånt e sisse“, paa Jysk: „A wånte(r) e(n) sisse“.

e) Last not least den bekendte jyske Artikel; jeg stiller den sidst, fordi dette Punkt egentlig alene kan bruges af den, der gør Jysk til Tysk, ikke saa godt af den dansk folkelige Opfattelse, uden forsaa vidt den er

1) Desuden er der den Forskel, at den tyske Opfattelse ikke indskrænker sig tll den umiddelbare Iagttagelse fra det moderne Sprog, den strækker sig ogaa ind over den lærde Argumentation, idet den tillige forer Oldsprogene i Marken. Det el naturligvis for højt for den folkelig danske Opfattelse, netop fordi den er en Lægmands-Opfattelse. Jfr. S. $27 \mathrm{ff}$. 
rent uvidende om, hvordan Tysk seer ud. Jysk (d. e. Vest- og Sønderjysk) sætter den bestemte Artikel foran Hovedordet ligesom Engelsk (og Tysk), ikke bagefter som Nordisk, $æ$ Mand (tidligere sikkert: thæ Mand, dæ Mand), eng.: the Man, (tysk: der Mann), men nord.: Manden.

Saavidt de foreliggende Ligheder. Men alt det betyder ingen Verdens Ting; man behøver bare at gaa til de foreliggende Oldsprog fra det $8 \mathrm{de}-10 \mathrm{de}$ Aarh. for at overbevise sig om, at det hele er Tilfældighed, at Overensstemmelser og Uoverensstemmelser fordeler sig paa en helt anden Maade

1. I Oldtiden var Udtalen med Dobbelt-V fælles for hele Norden og Tyskland med. 2. Jysk W i Wonsdaw har slet intet at gøre med W i engelsk Wednesday; det hed éngang i Jysk som i alt andet Nordisk "Odinsdag", W'et er et senere Forslag, ligesom i Jysk Wolle for oldnordisk Olaf eller som i Wost for Ost, hvor der oprindelig stod J (jfr. finsk: juusto, Ost). 3. Paa Oldengelsk hed det (ligesom paa Oldtysk) bindan, ridan, medens det paa Oldjysk ligesom paa Oldnordisk hed binda, rida. 4. „Jeg“ hed paa Oldengelsk ligesom paa Oldnedertysk „ic“, paa Oldjysk ligesom paa andet Oldnordisk „ek“ eller njak“. Udsagnsordet "to want“ var tidligere fællesnordisk. "Scissor“ er hverken Oldengelsk eller Oldjysk, men Latin. 5. Den vest- eller sønderjyske Artikel. Dette er det eneste Punkt, hvor Lighederne mellem Jysk og Engelsk ikke opløser sig til intet, saasnart man blot gaar tilbage til de foreliggende Oldsprog; i Oldnordisk har vi jo faktisk den efterhængte Artikel, og selv om den foranstillede Artikel ikke optræeler i det foreliggende Oldjysk, saa optræder ligesaalidt den efterhængte: der forekommer nemlig 
overhovedet slet ingen bestemt Artikel ${ }^{1}$ ). Paa dette Punkt er der altsaa en Mulighed for, at Jysk paa Folkevandringstiden har staaet nærmest ved Tysk-Engelsk- (og Gotisk), men kun en Mulighed, thi ingen kan bevise, at det øvrige Nordisk paa Folkevandringstiden ikke ogsaa har haft den foranstillede Artikel i alle Tilfælde, - at møde op med det 9de Aarhundredes Nordisk er at komme med tyndt øl. Men selv om Forskellen gaar tilbage til Folkevandringstiden, saa er ialfald den jyske Artikel som Bevis for Jyskens Tyskhed kun at ligne ved den Fjer; hvoraf man gjorde 7 Hons. Vi gør bedst $i$ at lade Nutidsjysken ligge som det, den er.

Hermed er vi færdige med den umiddelbare Opfattelse, baade den danske og den tyske.

II. Den ældre lærde Opfattelse. - Dens Grundlag er netop givet med den Kritik, vi ovenfor anvendte mod den umiddelbare Opfattelse: hvor det gælder Oldtidsforhold, skal vi naturligvis ikke sammenligne $\mathrm{Ny}$ engelsk med Nyjysk og Nytysk, vi skal gaa til Oldsprogene, sammenligne Oldengelsk med Oldtysk og Oldnordisk. Vi vil da finde, at Engelsk er et afgjort tysk Sprog. - Her mødes atter Danske og Tyske i Enighed ligesom ved den umiddelbare Opfattelse; naturligvis er der ogsaa Uenighed ved Siden af, blot golder denne nu ikke Sproget, men Hjemstavnen. Tyskerne staar $i$ dette Kapitel endnu paa det umiddelbare Trin, forsvarer Bedas Angelboer; Danskerne repræsenterer den videre fremskredne Udvikling, den strænge Kritik, der forkaster Beda Det maa for-

1) Uden ved Adjektiver, hvor alt Nordisk i det mindste overvejende bruger den foranstillede Artikel: „den hele Tid, den starste $\mathrm{Del}^{\text {" }}$ ved Siden af "hele Tiden, stgrste Delen". 
øvrigt bemærkes om Kritiken mod den umiddelbare Sprogopfattelse, at direkte udtalt bliver den vel kun af de danske Lærde, hvem Sammenstillingen af Engelsk og Jysk var politisk imod, - de tyske derimod, hvem denne forkerte Sammenstilling kun kunde være velkommen, lod den passere, og mere end én var elastisk nok til at kunne anvende Nutids-Sprogsammenligningen i samme Aandedræt, som han selv ophærede den ved at anvende OldtidsSprogsammenligningen. Men stiltiende øvedes Kritiken af -enhver tysk Lærd, der konsekvent holdt sig til Oldsprogene og afholdt sig fra Nutidssprogene. - Saavidt Standpunkterne; nu nogle Illustrationer. Overfor den umiddelbare Sprogopfattelse har vi allerede nævnt de oldengelskoldtyske Fællesformer ic, binda, ridan, Woden modsat oldnordisk ek (jak), binda, riða, Oðinn. Andre Exempler er Ejeformen af Ulv, ung; oldeng., oldtysk. : wulfes, giunges (junges), modsat oldn.: ulfs, ungs; eller Genstandsform af Unde (Saar); oldeng., oldt.: wunde, modsat oldn.: und. Og saaledes helt igennem: overalt kaster Oldnordisk af baade for og bag, og unægtelig ser Oldengelsk og Oldtysk i Sammenligning dermed ud som ét og samme Sprog. Man kan ikke tvivle om, at omkring Aar 800 forstod Englænderne og Tyskere hinanden betydelig bedre end Englændere og Nordboer gjorde. Det er aldeles korrekt og praktisk nødvendigt $i$ Grammatikundervisningen at sondre Vikingetidens oldnordiske Sprogtrin skarpt ud fra de engelsk-tyske Oldsprog. Men naar den Lærde uden videre overfører dette Skel paa Folkevandringens Sprog, bærer han sig ikke et Haar bedre ad end den umiddelbare Sprogopfattelse, som han vil være saa højt hævet over; den umiddelbare Iagttagelse finder Overens- 
stemmelser mellem Nyengelsk og Nyjysk modsat Nytysk eller Nynordisk, men tænker ikke paa Oldsprogene; den lærde Iagttagelse finder Overensstemmelser mellem oldengelsk og Oldtysk, men tænker ikke paa Ursprogene.

$\mathrm{Nu}$ mar det siges til de ældre Lærdes Undskyldning; at med Ursprogene var der paa Forskningens daværende Stade ikke meget at stille op, navnlig var man endnu ikke naaet til de epokegørende Tydninger af de urnordiske Runeindskrifter. Det var da ret tilgiveligt, om man skød Skellet mellem Nordisk og Tysk længere tilbage i Tiden, end videnskabelig Forsigtighed strængt taget kunde tillade. Men naar de danske Historikere den Dag idag hævder det gamle Standpunkt, at Nordisk er himmelvidt forskelligt fra Engelsk, gælder Undskyldningen ikke længer. Det nordiske Ursprog er nuomstunder mer end tilstrækkelig bekendt gennem Bugges og Wimmers Tolkninger af Guldhornsindskriften etc., og længer behøver man ikke at gaa for at finde det skønneste Udvalg af „tyskengelske" Former som ik, bindan, ridan, wulfas, jungas, wunda. Man vil maaske synes, at de urnordiske Former ikke stemmer aldeles nøje med de oldengelsk-tyske, f. Ex. hedder det i Ejeform urnord.: wulfas, men oldeng., oldtysk: wulfes. Man rekonstruerer vi Urformerne i de ovrige Sprog, hvad vi her mell fuld Sikkerhed kan gøre, kommer vi i Engelsk netop til Formen wulfas, derimod er i Tysk og Gotisk wulfes den oprindelige Form. - Det viser sig altsaa, at Oldnordisk forholder sig til Oldengelsk netop som den arm- og benløse Person $\mathrm{C}$ til den velbeholdne Person A, og at C's Arme og Ben, dengang han havde dem, mangengang lignede A's mere, end Tilfældet er med B's, der ligesom A har Arme og Ben i Behold. - Eller 
vi kan sige: Sprogsammenligningen viser sig som et kinesisk Æskespil: i det yderste Lag ligner Engelsk en nordisk Dialekt (Jysk), - piller vi dette Lag af, kommer Engelsk til at ligne Tysk, og graver vi ind til det allerinderste Lag, støder vi atter paa Lighed med Nordisk. ${ }^{1}$ )

De af mig fremdragne Exempler maa være mer end nok til at vise, hvor vildledende den Sprogbetragtning er, som uden Forbehold kalder Engelsk for Tysk. Det være nu langt fia mig at paastaa, at det forholder sig saadan med alle de tysk-engelske FællesAfvigelser fra Oldnordisk. En stor Del af dem naar virkelig tilbage til Urtiden; dem faar man saa veje imod Urtidens engelsk-nordiske Fællesafvigelser fra Tysk. Kun paa den Maade kommer man til Anglernes Sprogniveau før Udvandringen.

III. Den nuværende lærde Opfattelse. Dens Grundlag er netop givet negativt i Kritiken af den ældre lærde Opfattelse, positivt i den ovenfor sidst udtalte Sætning, og paa dette Grundlag naar den til det mæglende Resultat, at Engelsk og Tysk vel hører sammen til én Gruppe, modsat Nordisk, men at Engelsk ingenlunde kan kaldes Tysk, og at det paa mange Punkter viser et Fællesskab med Nordisk, der i og for sig ogsaa maatte ventes efter dets geografiske Mellemstilling. Her mødes endelig atter Danske og Tyske, men dennegang $\mathrm{i}$ fuld Enighed, baade om Sproget og Hjemstavnen, idet i det mindste

1) Der viser sig den Pudsighed, at medens vi ved jysk Wonsdaw maatte erklære: "W'et har ikke noget med W i Wednesday at gøre, fordi det paa Oldjysk hedder Odinsdag", kommer vi i Urnordisk virkelig til det oprindelige W paa denne Plads, paa Urnord. hed det nemlig Wodenas-. 
adskillige tiltræder den kritiske Resignation ovenfor Bedas Beretning om Anglernes Herkomst fra Angel. Exempler paa Argumentationen er givne ovenfor ved Kritiken af den ældre lærde Opfattelse.

Den moderne Kritik kommer over den ældre Kritik som Høg over Høg, imidlertid er den endnu ikke naat saa højt, at man jo kan komme højere, thi den lider selv af en betydelig Skævvingethed. Det illustreres bedst ved en Lignelse. Naar man f. Ex. vil afgøre, om en Abekat staar nærmest ved Menneskene eller ved Dyrene, sammenligner man saa paa den ene Side et Menneske, paa den anden Side en Hvalfisk? Nej, thi saa maatte man jo absolut komme til det Resultat, at Aben staar nærmere ved Mennesket end ved Dyrene, og det vilde dog ialfald mange kalde et skævt Resultat. Man tager derimod som Repræsentant for Dyrene en Hund, Kat, m. a. 0 . et Exemplar, der kommer saa nær op mod Aben i Udvikling som muligt. Men hvordan har man baaret sig ad ved sproglige Sammenligninger? Man har sammenstillet Engelsk paa den ene Side med Oldnedertysk, paa den anden Side med Oldislandsk, d. v. s. paa den ene Side den nærmest mulige Repræsentant for Tysk, paa den anden Side den fjærnest mulige Repræsentant for Nordisk. Jeg skulde endda være tilbøjelig til at tro, at Oldnedertysk staar Oldengelsk nærmere end tilladeligt for at benyttes til Sammenligning, idet det rimeligvis er et ligefremt Blandingsprodukt af Angelsaxisk og Tysk, opkommet dengang Nordtysklands saxiske Beboere i tusendvis uddreves af Karl den store og erstattedes med Tyskere. Isaafald er det ikke en stort bedre Repræsentant for Tysk end f. Ex. det „Højtysk“, der tales i Flensborg, og som er et Misk- 
mask af Tysk og Dansk i Ord- og Sætningsbygning. Det faar nu staa hen, men saa meget er vist, at vil man sammenligne Oldengelsk med Oldnedertysk paa ene Side og Oldnordisk paa den anden, og saa som Repræsentant for Oldnordisk tager Islandsk, -- da er det ikke stort andet end at sammenligne Aben med Mennesket og Hvalfisken. Nej vil man sammenligne Engelsk med noget paa nordisk Side, maa det selvfølgelig være Dansk, og særlig Jysk. Og jeg skal strax paavise, at man ved at undlade det, faktisk har oversét Ting, som ikke er uvæsenlige. Jeg sigter her ikke til den "jyske Artikel“. Den har man som ovenfor omtalt ikke oversét, tværtimod er der af tyske Sprogfuskere i politisk Øjemed lavet syv Høns ud af denne ene Fjer. Derimorl har man faktisk oversét, hvad jeg nu skal gøre opmærksorn paa. En af de Lydudviklinger, som regnes til $\mathrm{d} \bullet \mathrm{m}$, der betegner Oldengelsk, er Overgangen af $\mathrm{O}$ til $\mathrm{U}$ og delvis $\mathrm{F}$ til $\mathrm{I}$ foran $\mathrm{M} \circ \mathrm{og}$. - F. Ex. hedder det niman, genumen modsat tysk: nehmen, genommen og ,oldnordisk" (d. e. norskislandsk) nema, nomenn. Men sér vi efter, hvad det hedder paa Olddansk og Oldsvensk, finder vi det. selvsamme som i Oldengelsk, nemlig nima, numen (jfr. fornummet). Lydloven er altsaa slet ikke særegen for Oldengelsk, men fælles for Oldengelsk, Olddansk og Oldsvensk. - Det er ét Exempel, og hvem tør svare for, at der ikke vil findes flere? Man vil ialfald ikke kunne benægte Nuligherlen, saalænge man slet ikke har tænkt paa at undersøge Sagen. Forresten er der ogsaa adskillige Ting, hvori hele det nordiske Sprogomraade stemmer merl Engelsk modsat Tysk, og som de hidtidige Sammenlignere har forbiganet, men det maa hellere vente til et særskilt 
Afsnit. Det er ikke af væsentlig Betydning par nærværende Sted, da det dog ikke er tilstrækkeligt til at rokke ved det Hovedresultat, hrorved den moderne Sprogforskning er bleven staaende.

Men selv om vi maa blive ved, at Engelsk i Urtiden staar let senere Tysk nok saa nær som det senere Nordisk, er det dog urokkelig fastslaaet, at det indtager en Mellemstilling. At kalde det "afgjort tysk" er ikke blot en mislig Foregribelse, det er positivt forkert.

Heller ikke i den senere Sprogudvikling gaar det an at kalde Engelsk for tysk, selv om det en Tid lang bliver staaende tæt ved Tysk paa samme ældre Udviklingstrin, modsat Vikingetidens hovedkulds fremskridende Nordisk. Hvis man vil 'gøre dette rent midlertidige og passive Fællesstade til Grundlag for en snæver Slægtskabsgruppe, kan man meget bedre med den folkelig danske Opfattelse opstille Gruppen Engelsk-Jysk eller Engelsk-Dansk, thi i sirdste Instans er jo Engelsk i aktiv Udvikling, d. v. s. i Afslibning af Former, naaet op til Dansk, ja videre endnu, medens omvendt Islandsk ikke er kommet videre end $\mathrm{i}$ Oldtiden $\mathrm{og}$ er indhentet selv af Tysk, der jo ellers udmærker sig ved en tilstrækkelig gammeldags og besværlig Granmatik.

En Sag for sig er det naturligvis, at praktiske Hensyn af sig selv maa stille det oldtysk-oldengelske Fællesstade i Forgrunden. Den gamle Sprogundervisning og Literaturlæsning er af gode Grunde fri for at lægge Urstadet til Grund, fordi dette nemlig kun er os overleveret gennem ganske fat Brudstykker og gennem de Lærdes Rekonstruktioner. Det ældste sammenhængende i Sprog og Literatur er Oldstadet; det maa man gaa ud 
fra i den praktiske Brug; man maa saa foretage de Sammenstillinger og Adskillelser, der paa dette Grundlag indfinder sig af sig selv, d. v. s. man maa drage et skarpt Skel mellem Oldengelsk-Oldtysk paa den ene Side, Oldnordisk paa den anden. Naar man vil sammenligne Oldengelsk med Oldnordisk, maa man som Repræsentant for dette tage Oldislandsk, fordi det er den eneste gældende og tilgængelige Literatur-Repræsentant, ialfald saalænge den nordiske Undervisning er saadant Stedbarn, som Tilfældet nu er. Men man maa aldrig glemme, at det netop kun er praktiske Grunde, der paabyder denne Fremgangsmaade, man maa aldrig ophøre med at advare mod de forkerte Konsekvenser, der vil blive Følgen, hvis man stoler paa dette praktiske Materiale som Grundlag for en videnskabelig Kritik.

Tilslut endnu et Par Ord om Engelskens Dialekter og deres Navne. Efter den gamle Overlevering bestod Englænderne af Angler, Saxer og Jyder, og Sprogforskningen finder Oldengelsk spaltet i tre tilsvarende Hoveddialekter. Heraf har Enkelte konstrueret sig en særlig Opfattelse, som ikke enten regner Engelsk til Nordisk (henholdsvis Tysk), eller giver det en Mellemstilling, men istedenfor deler det midtover: Anglisk og Jysk er Dansk, Saxisk er Tysk. De Saxer, vi kender paa Fastlandet, er jo i Nutiden faktisk Tyskere, men naar man af den Grund vil kalde de engelske Saxer for Tyskere, er det ikke andet end en af de sædvanlige Foregribelser, og med langt større Ret kunde man kalde de tyske Saxer for Englændere. De engelske Saxers Sprog adskiller sig i intet væsentligt fra de engelske Anglers, og intet tyder paa, at det har været anderledes, f. Ex. at let engelske Saxisk skulde 
være bleven angliseret. Derimod er der paa de tyske Saxers Omraade stærke Spor af Denationalisering; Sprogrester fra det 10de Aarh. viser, at der endnu dengang taltes en angelsaxisk Dialekt $i$ det sydøstlige Hannover, og den Dag idag ligger denne Dialekt forstenet i Stednavne. Et Exempel er det bekendte hannoverske "Celle" (udtalt "Tselle"); det har intet med vort (latinske) "Celle" at gøre, men er ganske simpelt vort „Kilde“, plattysk "Kelle“, højtysk "Quelle“. Navnet skreves tidligere "Kielle“, "Cielle" etc Overgangen fra $k$ til $k j$, t $j$, ts $(j)$ foran e og i er den samme som i Nutidens Jysk, Svensk og Norsk, men den er megret ældre i Engelsk og Frisisk, og paa den Maade et Hoved-Særkende for den engelskfrisiske Sproggrupple. (Jfr. engelsk „church“, udtalt „tjøetj“, fris. "tsirk“, vort "Kirke“, plattysk "Kerke“, højtysk „Kirche".) Naar vi derfor i en tysk Egn, hvor „Kilde" hedder "Kelle“, finder et Bynavn som Celle, véd vi, at vi staar paa fordums angelsaxisk eller frisisk Grund, paa samme Maade, som Navnet "Schleswig" rober os, at vi staar paa fordums dansk Grund, - paa ægrte Tysk skulde $\mathrm{k}$ være bevaret, altsan: „Sleswik, Schleswick“ ell. 1. Hvorledes Saxernes Fortyskning er gaaet for sig, hører vi ikke direkte Tale om, og det behøver ikke at undre os, da Sprogforskellen dengang endnu var saa ringe. Men et lille Fingerpeg giver Historien forresten alligevel, naar vi hare vil forstaa den ret. Vi har alle læst om Karl den Stores Religionskrige mod Saxerne, om den saxiske Bloddaab etc., men de færreste vide, at Karl den Store lod 10,000 Saxer flytte bort fra Holsten og en Del af Nordøsthannover til Franken, Gallien etc., og $\mathrm{i}$ deres Sted indflyttede andre Folkestammer (Finhard, Karl den Stores 
Levned, Kap. 7). Holsten har nuomstunder ca. 560,000 Indbyggere; dengang har det neppe haft en Tiendedel. Det var altsaa en forsvarljg Aarelarining, Karl den Store gav det saxiske Element, og den aller haandgribeligste Fortysknings-Methode, som tænkes kunde.

Saavidt det engelske Saxisk i Forhold til det tyske Saxisk.

Tilbage staar Forholdet mellem det engelske Jysk og det danske Jysk. Det engelske Jysk er ligesom det engelske Saxisk en ren engelsk Dialekt; der lader sig ikke paavise noget særligt Frendskab med dets Navnefælle paa Fastlandet. Her er nu flere Muligheder. 1) Forholdet kan være najagtig som ved Saxisk: den engelske Dialekt er den direkte Fortsættelse af den oprinielige Dialekt, derimod er Fastlandsdialekten denationaliseret, her altsaa: fordansket. 2) Det er muligt, at det engelske Jysk er angliseret; det indtatrer ikke som det engelske Saxisk et betydeligt Rum, men kun et ganske lille, Halvøen Kent, der let kan trenkes at have føjet sig efter Nabodialekten. En saadan Anglisering foreligger ubestridelig paa Øen Wight, der ogsaa er befolket af "Jyder“, men hvis Dialekt ikke er den engelsk-jyske, men den samme som de omgivende engelske Saxers. 3) Det er muligt, at hverken det engelske eller det danske Jysk er Fortsættelse af Crjysken. Det ene kan være angliseret, det andet daniseret. 4) Endelig er der den Mulighed, at de engelske Jyder ikke har det mindste med de danske at gøre; herom i næste Afsnit.

Jeg holder nærmest paa den tredje af de nævnte Muligheder, jeg anser Urtidens Jysk snarest for „det 
manglende Led“ mellem Engelsk og Dansk. Dette Led ma have existeret; er det ikke Urjysk, saa er det en anden Urdialekt. Den sproglige Kendsgærning, at Dansk staar Engelsk noget fjærnere, end Tysk gør, forudsætter, at Dansken oprindelig har levet $i$ en Egn, der ikke laa i Engelskens umiddelbare Nabolag, og det stemmer paa det najeste med den gamle historiske Overlevering. (Jfr. Jordanes, Goternes Historie, Kap. 3, der lader Danerne udgaa fra Sverig og fordrive Herulerne, og endvidere det danske Nationalsagn i de gamle Kroniker, der lader Dan udyaa fra Sverig og først herske udelukkende over Sjælland, Laaland, Falster og Møen.) Den i Sverig udvikiede mere nordlige Sprogferm tog Danerne med sig til Øerne og Jylland, de bragte saaledes disse Egne til sproglig at rykke noget nærmere mod Norden og fjærnere fra Angelsaxerne. Saaledes ophører Engelsken at staa lige midt mellem Dialekterne paa begge Sider" Men det berører aldeles ikke vort Spørgsmaals Karnepunkt, det nationaltkulturelle. Thi man maa ikke uden videre identificere Sprog med Nationalitet og Nationalkultur; fordi Anglerne staar nærmere ved Tyskerne end ved Nordboerne i Sprog, behøver de ikke at have gjort det i Kultur. Jæunfør blot Forholdet mellem Nutidens Danske, Svenske og Tyskere. Dansk og Svensk er kun Dialekter af samme Sprog, Danske og Svenske forstaar hinanden taalelig uden at have lært hinandens Sprog, men derimod forstaar Danske og Tyske ikke hinanden uden at have lært hinandens Sprog. Og dog staar dansk og tysk Dannelse hinanden mindst ligesaa nær som dansk og svensk, adskillige vil vist sige: betydelig nærmere. Vort sproglige Resultat er altsaa neutralt overfor det nationale Spørgsmaal; dette maa undersøges 
nøje for sig selv og bedømmes udfra sine egne Forudsætninger.

Hermed forlader vi Kritiken af de aldre Sprogopfattelser.

\section{Kritik af de aldre Opfattelser af Anglernes Hjemstarn.}

De ældre Opfattelser var følgende:

1. a) Den umiddelbar folkelige - danske og tyske Opfattelse, og b) den lærde tyske Opfattelse, der sætter Anglerne i det sønderjyske Angel.

2. Den lærde danske Opfattelse, der sætter Anglerne i Mellemtyskland.

Den negative Kritik, der er.nødvendig til Sagens Klaring, findes nærmest hos den danske Skole, og det bliver altsaa dennes Opfattelse, vi faar at gøre med. Dens Hovedstøtte i Nutiden er Svenskeren Erdmann og nu sidst Professor Joh. Steenstrup i Danmarks Riges Historie. En Modkritik er, inden Steenstrups Værk udkom, given af Professor Herman Møller ved Københavns Universitet $i$ en udfırlig Anmeldelse af Erdmanns Bog (Anzeiger für deutsches Altertum, 1896) og for ganske nylig af August Sach (Das Herzogthum Schleswig, II. 4.) ${ }^{1}$ ) Jeg skal nu give en Oversigt over Hovedstøttepunkterne for Erdmann og hans Meningsfæller.

Det sproglige Bevis „Engelskens afojorte Tyskhed“ har vi kasseret. Tilbage staar følgende Vidnesbyrd:

1) Geografen Ptolemæus (2. Aarh. e. Kr., bygger paa romerske Kilder fra 1. Aarh. e. Kr.) sætter Anglerne ved Mellemelben, som østlige eller nordøstlige Naboer til Langobarderne.

1) Prof. Jespersen, der i Salmons. Konvers. Lex. (Engelsk Sprog) havde sluttet sig til Erdmann, har efter Fremkomsten af Prof. Møllers vægtige Indlæg ændret sin Opfattelse til Tvivl. 
2) Tacitus (i sit Værk „Germania“, Kap. 40, [1. Aarh. e. Kr.]) nævner Angler ved Siden af Langobarder og Variner. Kilder fra Folkevandringstiden og senere (Prokop, Gregor af Tours, Adam af Bremen) kender Angler og Variner (Veriner, Varner) ved Rinens Udløb, nær ved et Landskab Thoringen, nu Doringen. Disse havde en fælles Lov, hvis Titel er os bevaret fra Karolingertiden: „Lov for Angler og Veriner, d. e. Thoringer". - Varnerne var altsaa Anglernes Brødre, deres Hjem maa være Anglernes nærmeste Nabulag. Selvfølgelig er Rindeltaet ikke deres $\mathrm{Hjem}$, her er de Udvandrere, ligesom de Chauker fra Hannover og Saxer, der optrader i de samme Egne. Tacitus, der omtaler dem i Hjemlandet, giver ingen nærmere Stedfæstelse. Derimod kender Historien (Prokop etc.) et Varnerrige i Mellemtyskland, just i de Egne, hvor Ptolemæus sætter sine Angler.

3) Gamle Jordebøger etc. næ*vner i de samme Eque et Landskab „Engilin-gau", der kan betyde "Angler-herred", ved Siden af et "Warino-feld", "Varnernes Mark" og et "Fresono-feld", „Frisernes Mark". Angler og Friser er, som ovenfor bemærket, sproglig ner beslægtede. (Jfr. Niederd. Jahrb. XII. S. 20).

4) Sprogrester fra det 10de Aarhundrede og Stednavne riber, at her faktisk har været talt en angelsaxisk eller frisisk Dialekt. (se ovenfor Side 35).

5) Saxernes Nabulag. Saxerne var Anglernes Fæller ved Englandstoget. De boede efter Prof. Steenstrup i det 4. - 5te Aarh. paa Elbens venstre Side, og det passer daarligt som Nabolag til Angel, derimod udmærket til det thyringske Angelland højere op ad Elben.

Saavidt Vidnesbyrdene for Erdmanns og Steenstrups Opfattelse. En Ting fremgaar deraf med Sikkerhed: der har virkelig boet Angler dér, hvor Ptolemæus sietter dem.

Der skal da meget vagtige Vidnesbyrd til for at omstyde den Slutning, at Anglerne har boet her uafbrudt siden Ptolemæus' Tid.

De modsigende Vidnesbyrd er forlgende:

A. Om Anglerne i England.

Den samlede oldengelske Overlevering gaar ud fra Hjemlandet Angel som en Kendsgærning, hvorom det ikke falder nogen ind at tvivle. 
1. Sætningen, Anglerne kurn fia Angel, mellem Jyder og Saxer" udtales direkte af en lang Række Forfattere, dels afskreven fra den ene til den anden, dels ogsaa fursynet med selvstrendige Tilføjelser.

a) Anglerfolkets Kinkehistoriker Beda den ierværdige (f. 673 + 735), derefter hos Wessexkroniken. hus Kong Alfred den Store (849-901) og hos Walesmanden Nennius (796). Beda siger, at Jyderne fulgte med Anglerne paa Toget, og at Angel nu ligger sde

b) Others Rejsebeskrivelse (ca. 875), Historikeren Lthelwerd (ca. 960) etc. Her tilfajes Hovedstadens Navn; Other kalder den med en angelsaxisk Narneform næt Hæpum" ("ved Hederne"), Ethelwerd nærner den danske Form "Haithaby" og tilføjer, at paa Saxisk hedder den Slesuuic. Vilhelm af Malmesbury (12. Aarh.) siger, at "Slaswich" er det ældre Navn, Eitheisi (hes Heithiby) det yngre.

2) Egte folkelig er Sprogformen, som lyder "Ongel“" (Hensynsform "Ongle" hos Alfred og i Digtet Vidsid; "(Ighgul" hos Nennius). Dette kan ikke være en Overførelse fra Anglernes Provins i England, thi denne hed (East-)Engle, d. e. Flertal -"Angler ${ }^{4}$. Men det kan heller jkke være en Overførelse fra det sønderjyske Navn, thi dette har altid paa Dansk og Tysk heddet Angel(n). Det kan kun være den angelsaxiske Form, gaaet fra Mund til Mund $i$ ægte folkelig Overlevering; paa Angelsaxisk bliver ethvert a foran $\mathbf{m}$ og $n$ i Reglen til o. - Egte angelsaxisk folkelig er maaske ogsaa den selvstændige Navneform "æt Hæpum ${ }^{4}=$ dansk Hedeby.

3) ${ }_{\text {"Ongel }}{ }^{\alpha}=$ Anglernes Fædreland forudsættes i Vidsiddigtet som noget, der er hrert Barn bekendt. Vidsid er omtrent den æeldste existerende Literaturleming fra England (7de Aarh.), og indeholder geografisk-historiske Hjemlands-Erindringer fra ældgammel Tid (fra før Goternes Udvandring, 3. Aarh. e. Kr.)

4) Vilhelm af Malmesbury beretter, at Sceaf herskede i Slesvig. ${ }_{n} \mathrm{Sceaf}^{*}$ betyder "Neg", han er en mythisk Figur, Fader til Kong Skjold, og spiller en stor Rolle i oldengelske Sagn; i Vidsid kaldes han Konge over Langobarderne, der stod Anglerne nær.

5) Vidsid fortæller, at "Ongel"s Grænse ved „Fifel-dor", $d$ e. "den skrækkelige Dor" (Vandvej) værges af en navnkundig Kong Offa, og han er Søon af Værmund, en Efterkommer af Vithlæg, der opføres som angliske Kongestamfædre i Merciarigets Kongerække. Jfr. den danske Overlevering hos Saxe, hvor Angels (og Jyllands) Grænse ved Eideren, ældre Age-Dør, ,den skrækkelige Dør ${ }^{*}$, værges af en navnkundig Konge Uffe, Swn af Vermund, blandt hvis Forgængere findes en Viglek. Beovulf Vers 1957 


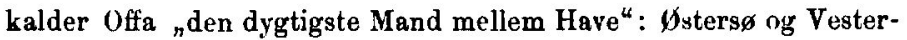
hav; passer atter kun paa Jylland.

6) De østangliske Kongers Stamtavle opfører en Kong Frẻavine og hans Sun Vig, som hos Saxe er Jarler af Sønderjylland (Frøvin, Vigo). Altsaa igen: "Ongel" ${ }^{\prime}=$ Angel.

7) Den danske Kongerække (hos Saxe etc.): „Angel er Broder til Dan."

\section{B. Om Anglernei Mellemtyskland ogved Rinen.}

8) En lille anonym Krønike, som omtales af Müllenhoff (Zeitschrift f. deutsch. Altertum. 1874, S. 57) og er fremdraget af $\mathrm{Hr}$. L. Lund i Nationaltidende for 2. Oktober 1899, fortæller, „at i Norden (in plaga septentrionali) ligger ved Havet et Landskals ved Navn Swevia, hrorfra, som Følge af Hungersnod, en Del af Befolkningen udvandrede og sejlede til "en Havn i Danernes Land paa et Sted, der hedder Slesvic". Herfra drog de til Floden Alba (Elben). Der var paa den Tid Krig mellem Frankerkongen Theoderik af Austrasien og Thyringerkongen Irminfrid, og den forste lovede de fra Slesvig kommende "Swevere" Landet ved Floderne Sala og Salza, hvis de vilde bjælpe ham i Kampen, hvilket Land de efter Thyringernes Nederlag ogsaa fik."

9. Adam af Bremen (I, 3) siger om Anglerne og Varnerne red Rinen, at en Del af dem drog til Britamuien, en anden Del til Thyringen. (Sach, II, 74.)

\section{Om Saxerne, Anglernes Nab of olk.}

10. Ptolemæus sætter Saxerne udelukkende i Holsten, altsaa i Angels Nabolag, ikke sønden- og vestenfor Elben, i det thyringske Angellands Nabolag.

11) De tyske Saxers Histurieskriver Widukind (10de Aarh.) meddeler et saxisk Nationalsagn, at Saxerne kom over Havet, landede i Hadeln (Hannovers Nordspids) og fordrev Thyringerne.

12) a. (Citat efter L. Lund) „Rudolf af Fulda og Adam af Bremen berette efter en fælles Kilde, et nu tabt Skrift af Einhard, Karl den Stores Samtidige (der atter paaberaaber sig ældre Kilder), at "Sachsere, der udgik fra de Angler, der beboede Britannien", (Saxonum gens, sicut tradit antiquitas, ab Anglis Britanniae incolis egressa), sejlede over (Oceanet til Germanien paa den Tid, da Theoderik bekæmpede Irminfrid, og af Frankerkongen fik Landet ved Floden Unstrota til Lon for ydet Hjælp i Kampen. ${ }^{*}$ 
b. „En tredje Beretning findes i de Qucdlinburgske Annaler, hvorefter i Kejser Justinians sjette Aar (532, rigtigere maaske 531) Kong Hugo Theodericus, Chlodvigs Slegfredsøn, fik Hjælp af ${ }_{n}$ Sachsere" til at bekæmpe Thyringerne og som Lon derfor gav dem Landet ved Floderne Sala og Unstrada."

Saavidt Modsigelserne mod de Virlnesbyrd, hvorpaa Erdmann og Steenstrup støtter sig. Om ét kan vi forelobig være enige, at er Modsigelserne ikke andet, er de ialdfald mange. Men der kan jo maaske gives Bortforklaringer, og af saadanne kender jeg eller kan trenke mig frlgende:

1. Det sønderjyske Angel er altfor lille til at have rummet Anglerne, der erobrede hele Mellem- og Nordengland. I historisk Tid er det politisk Nul, ikke engang et serligt Herred, Navnet betegner slet og ret "Krogen", d. e. mellem Slien og Flensborg Fjord. Bedas Fortælling er lærd Gætværk, fremkaldt ved den tilfældige Iighed mellem det sinderjyske Angel og Anglernes Navn. Hans Jyder er paa samme Maarle en Forvexling; det er i Virkeligheden de nordtyske "Euthier".

$2,3,4,5,6,7$. De qvrige Vidnesbyrd, der synes at hensatte Anglerne til det sønderjyske Angel, er fremdeles Forvexling eller vilkaarlige Tillempninger. Sagnene om Vermund-Uffe og Frøvin-Vig er komne med danske Vikinger til England, hvor de jysk-angelske Herskere tilegnedes som engelsk-angliske i Kraft af Bedas Gisuing. Fortællingen, at Angel er Broder til Dan, skal vare et Sindbillede paa Fnglands Forbindelse med Danmark i Vikingetiden.

8. Den anonyme Krønike er forvirret; den fortæller om Anglerne den selvsamme Ting, som i Nr. 11-12 fortælles om Saxerne, altsaa atter Forvexling. 
9. Beretningen hos Adam af Bremen er ganske tydelig forvirret; han lader Anglernes Englandserobring udgaa fra Rinegnene istedenfor fra Elbegnene. (Samme Fejltagelse hos Prokop).

10. Holsten er altfor lille til at have rummet Saxerne, der erobrede hele Sydengland og Frankrigs Nordkyst.

11-12. Overfor disse Efterretninger vil der for (jjeblikket ikke falde mig nogen særlig Bortforklaring ind, men at Saxerne trænger frem $i$ Thyringen, lader sig jo ogsaa meget vel forene med deres af Steenstrup artagne Bopwele, hvis intet andet taler inod disse.

Saavidt Aff:erdigelserne. De bestaar jo hovedsagelig af Antagelser om Forvexlinger, Annexioner etc. Den slags Bortforklaringer kan være gode nok - NB. hver for sig. Men skal vi paa den Maade bortforklare en hel Række Vidnesbyrd, bliver Sagen i det mindste noget betænkelig. ()g enkelte af Forvexlings-Beskyldningerne viser sig ogsaa ved forste (Njekast som meget løst begrundede.

1. "Hjemlandet Angel er lierd Navneforvexling." Denne l'aastand er allerede vasentlig swækket ved Paavisningen af, at det oldengelske "Ongel" er agte folkeligt i T'dbredelse og Sprogform.

2. „Bedas. Jyder er i V'irkeligheden Euthier... Intet er rimeligere. Men at disse Euthier har boet i Nordtyskland, er slet og ret Gisning. Vor hele Viden indskræenker sig dertil, at Euthierne nærnes som Frankernes Fjender i det 6. Aarh. niellem Danerne paa den ene Side, Saxerne paa den anden. D. v. s. netop de danske Jyders Plads.

Ogsaa enkelte af de mere saglige Bortforklaringer viser sig strax som intetsigende. 
3. "Angels og Holstens Lidenhed" siger intet. Der haves talrige Exempler paa Folkenavnes Indskrumpning, saavelsom paa det modsatte, at et ganske lille Folk koloniserer Strækninger, der er 3-4 Gange saa store som Hjemlandet.

Det er ikke Bortforklaringer som ovennævnte, der skal veje de mange Vidnesbyrd i Vejret til Fordel for de faa. Langt snarere maa man spørge, om ikke de faa lader sig veje i Vejret til Fordel for de mange.

Erdmann - Steenstrups Bevisforelse har to Hovedstøtter :

1. I'tolemæus' Angler i Mellemtyskland. 2. De historiske Angler sammesteds. De to Vidnesbyrds gensidige Stutte synes unagtelig svar at rokke.

Men er nu Ptolemaus virkelig saa sikker en Støtte? For at kontrollere det, maa vi tage Anglernes Ongivelser i (Xjesyn. I'tolemæus sætter Anglerne som østlige eller nordøstlige Naboer til Langobarderne; disse staa ogsaa hos Tacitus i Anglernes Nabolag, og kulturelle Berøringer viser, at de faktisk stod Angelsaxerne meget nær. Det vil altsaa være vigtigt, oin vi kan fastslaa, hvor disse Langobarder boede, saa har vi strax Anglernes Nabolag. Det véd vi nu meget godt: Langobarderne boede ved Nedre-Elben, i det nuværende Nordøsthannover, og deres Efterkommere bo dér rimeligvis den Dag idag i det Land, som efter ilem benævnes "Barden-Gau". Herhen naaede romerske Expeditioner og havde Berøringer med Folket. - Men hvor sætter Ptolemæus nu Langobarderne? Ted Nedre-Rinen. Det er en Egn, der var Operationsbasis for romerske Hære Aarhundreder igenmem, Dag 
ud Dag ind; den hører til de Egne af det senere Tyskland, der ligger $\mathrm{i}$ let fuldeste historiske Dagslys, næppe den mindste Folkestamme vilde kunne undslippe os her, endsige en vigtigere, og efter alt hvad vi vide, baade af Ptolemæus' Længdebestemmelser og andre Kilder, er Langobarderne endda en af de vigtigste. Men ikke én Kilde undtagen Ptolemæus nævner Langobarder her. De har aldrig boet der, end ikke vist sig der paa strejftog. ()g til Overmaal har Ptolemæus faktisk Langobarder paa det rigtige Sted, blot i en lidt fordærvet Form: „Lakkobarder"

Ser vi nu najere efter, finder vi hos l'tolemæus to Folkestammer ved đvre-Rinen: Cisper og Chaituorer, som kun kan være dem, der ellers hedder Lsiper og Chattuarer og bor ved Nedre-Rinen. ') Disse er altsaa forskudte mod syd til $h$ vre-Rinen fra Nedre-Rinen, Langobarderne er forskudte mod sydvest til Nedre-Rinen fra Nedre - Elben, og nu Langobardernes Naboer Anglerne, -- skulde ikke ogsaa de være forskudte mod Sydvest til Nellem-Elben fra et Stel ved Nedre-Elben eller nordligere? Enten det, eller ogsaa er Ptolemæus' Opgivelser overhovedet slet ikke anvendelige. Dette sidste troer jeg nu ikke; Ptolemæus er vel her som overalt fuld af Forvirring, men han kan dog bruges, omend rigtignok kun med største Forsigtighed. Principet maa være det, at han ikke tør bruges, hvor han modsiger samtidige Kilder; hans Betydning indskrankes derved til at væere en Bekræftelse og et Supplement til de andre Kilder, men det

1) Med et Bogstav eller to tagur Ptolemæus det ikke saa. nøje; jfr. Lakkularder $=$ Langobarder, Bugunter $=$ Burgunder, Busaktrer $=$ Buraktrer, Vargiones $=$ Vangiones etc. 
er dog altid noget, da hans Supplementer er meget righoldige. I foreliggende Tilfælde faar vi gennem Ptolemæus Bekræftelse paa det, vi erfarer gennem Tacitus' Beretning og gennem kulturel Sammenligning: at Langobarderne er Anglernes Naboer. Yi faar den nye Oplysning, at de er Langobardernes Naboer mod (xst eller Nordøst; derimod maa vi kassere den nærmere geografiske Bestemmelse, fordi Opgivelsen om Langobarderne strider mod samtlige Vidnesbyrd, ja mod Ptolemæus selv (d. e. mod hans Lakkobarder). Men det kan ogsaa være os ganske ligegyldigt, da vi i Forvejen mere end tilstrækkelig kender Langobardernes Hjemstavn, og derigennem atter med omtrentlig Sikkerhed kan bestemme Anglernes: da Langobarderne boede paa Nedre-Elbens venstre Bred, boede deres wstlige eller nordøstlige Naboer, Anglerne, selvfolgelig paa den højre, d. v. s. sydligst i (⿻)stholsten eller Laneuburg. Men derfra og til Sydslesvig er der kun et Hanefjed.

Altsaa konfronterer vi Ptolemæus forsvarlig med de samtlige Vidnesbyrd, maa han tilstaa, at hans Vidnesbyrd slet ikke stotter de thyringske Anglers Krav paa at eje de engelske Anglers Hjemland, - tværtimod, han maa siges at støtte det sønderjyske Angels Krav.

Tilbage staar altsaa kun den nøgne Kendsgarning, at der ef ter Folkevandringen boede Angler i Thyringen. De kunde naturligvis, Ptolemæus uansét, have boet dér fra Arilds Tid, men nu træffer det sig saa, at de eneste Vilneshyrd, vi har om deres Fortid, gaar demne Antagelse imol, idet begge lader dem indvandre under Folkerambingstiden, forst samtidiø med Fnglandseroh- 
ringen. Ldgangspunktet er efter begge Kilder et Land ved Kysten. Om den nærmere Bestemmelse er de uenige. Efter Adam af Bremen er det den angliskvarniske Koloni ved Rinen, hvorfra han ogsaa lader Anglerne gaa til Britannien, denne Beretning synes naturstridig, og maa vist bero paa en Forvexling af Rin- og Elbmundingen. Derimod konmer nu den anonyme Krønike med den direkte Beretning om Ldvandring fra det sønderjyske Angel. Hermed maa Bedas Efterretning betragtes som bevist, forudsat, at den nye Kildes Brugbarhed bekræfter sig. Om det kan man jo ikke have nogen afgørende Mening, saalænge den historiske Kildekritik ikke har haft Ordet, men man kan dog damne sig et Skon udfra en almindelig sandsynlighedshetragtning.

Jeg anførte selv den Bortforklaringsmulighed, at Krønikens Angler var en Forvexling med Saxer, om hvem den selvsamme Vandringshistorie fortælles af Vilnesbyrd 11-12. Men dermed kommer vi kun fra Asken og i Ilden, thi hvis Efterretningen er rigtig for Saxernes Vedkommende, viser den dog ligefuldt, at de omstridte mellemtyske Egne tidligere ikke var angliske eller saxiske, men thyringske.

Det gælder altsaa nu om at fastslaa Saxernes Udgangspunkt og Vandringsretning.

1. Hjemstavnen. Saxerne bo efter Prof. Steenstrup i det 4-5te Aarh. vestenfor Elben, fra preussisk Saxen til Zuiderswen. Dette er ikke ganske korrekt, thi Saxerne boede ogsaa nordenfor Elben til Ejderen, men ellers er det narnte saxland i den historiske Tid en ligesaagod Kendsgarning som Angellandet i Thyringen. Ogsaa den sproglige Kendsgerning er ulestrilelig, at den angel- 
saxisk-frisiske Sproggruppe før Folkevandringen maa have strakt sig fra Zuidersøen til Ejderen, om ikke længer. Men den angelsaxisk-frisiske Sproggruppe er ikke ét med de Angelsaxer, der erobrede Britannien. Dens vestligste Led, Friserne, deltager slet ikke i Erobringen, og vi maa altsaa nøjere undersøge, hvor langt mod Syd og Vest indenfor Gruppen Saxernes Navn har grebet om sig inden Ldvandringen, - videre tør vi ikke lade Deltagelsen i denne strække sig, ialdfald ikke uden nærmere Hjemmel. Og her er det jo ikke nok at gaa ud fra Karl den Stores Saxland, som man sædvanlig opererer med, thi dette er ialfald sine 2-300 Aar yngre end Englandserobringen og $\mathrm{i}$ en Folkevandringstid kan der ske meget paa 200 Aar.

Fra hvornaar dateres da Saxernes historiske Udbredelse?

a) Vor eneste Hjemmelsmand fra gammel Tia, Ptolemæus, kender Saxer udelukkende i Holsten. Han stottes af det saxiske Nationalsagn, der lader Saxerne lande ved Hannovers Nordspids: Hannover ligger altsaa udenfor Urhjemmet. Men Ptolemæus er igen for gammel: hans Kilder er fra det 1. Aarh., vi taler om det $4 .-5$.

b) Fra selve det 4. -5. Aarh. vide vi intet, men fra det 6te til det 8de finder vi Saxerne stadig i erobrende Fremtrængen mod Syd og Vest indenfor det senere Saxland. (Jfr. Beretningen om Thyringernes Fordrivelse ca. 530.) Endnu i let 7de Aarh. var Vestfalen ikke saxisk; Beda regner de derboende Bruchtrer, en gammel velkendt Stamme, for et særligt Folk og beretter om deres nylige Underkastelse under Saxerne (V, 11). Frisisk herskede nordenfor Vestfalen i hele Kystlandet mellem Zuidersøens 
Sydkant on Weserfludens Munding; endnu i det 12te Aarh. var det ikke fortrængt fra Zuidersøens Sydøstkyst (Grundriss f. germ. Phil. I, 637). I det 7de Aarh. naaede saxerne altsaa ikke langt ud over Weseregnen, hvor de Aar 553 led et stort Nederlag mod Frankerne, og Karl den Stores Masseomflytninger, der særlig gik ud over Holsten samt den umiddelbart tilgrænsende Del af Hannover, viser tydelig, at Holsten endnu $i$ det 8 . Aarh. betragtedes som Saxernes Hovedland. Et Saxland i det 4.-5. Aarh. "fra Zuidersøen til preussisk Saxen" er altsaa en fuldstændig Foregribelse; vi kan trøstig sige: Saxerne sad dengang som paa Ptolemæus' Tid i Holsten oy ikke stort videre. Dette passer da kun daarlig som Nabolag til Angellandet $\mathbf{i}$ Thyringen, ulige bedre til det sınderjyske Angel. - Men vigtigere er det andet Punkt:

2. Vandringsretninge n. Ifølge Erdmann-Steenstrup udvandirer Angler og Saxer fra Hannover, Thyringen etc. til England. Altsaa en Vandringsretning mod Nordvest. Kilderne siger: Angler og Saxer udvandrer fra Angel ( $\mathrm{g}$ Holsten el. Nabolag) dels til England, dels til Hannover, og Thyringen. Altsaa dels mod Vest (over Hav), dels mod Syd (over Land). Hvilket passer nu bedst med de foreliggrende Erfaringer fra Folkevandringstiden? Der kan ingen Tvivl vare: det gor Vandringsretningen mod syd. Det er en Kendsgarning, at alle de af vor Folkeklasses Stammer, der vandrede, fulgte Retningen mod Syd, enten helt eller delvis. (irunden er tydelig nok: det, der drog, var Kulturmagnetisinen, og den maatte drage Folkene mod Syd, mod Brændpunkterne $i$ den romerske Civilisation. De faa os bekendte Vandringer mod Nord er alle ganske særlig motiverede. Der er forst 
Friserne, der gaar mod Strømmen, idet de delvis vandre fra Romerrigets Grænseegne (Holland) mod det mere barbariske Norden, helt op til Vidaaens Udløb. Men Friserne er noget for sig; de er Marskboer, og hvad de gaar efter, er Marskstrækninger. Ogsaa deres Erhvervelser mod Syd, indenfor Romerriget, er netop Marskegne (Delta-Øerne ned til Schelde-Flodens Munding). Saa er der Saxerne og Herulerne. En Del af Saxerne var fra Thyringen dragen med Langobarderne til Italien, men blev utilfredse og vendte tilbage. Herulerne var fulgt med Goterne til Donauegnene; .her led de et Nederlag mod Langobarderne, og en Del drog saa op til Skandinavien, hvor de efter Jordanes' Ord hører hjemme (jfr. Professor Steenstrup i Danmarks Riges Historie, I. S. 82). Altsaa to Hjemvandringer. Endelig Anglerne selv. Hvad enten vi sætter dem i Angel eller i Thyringen, kommer deres Britanniens-Erobring til at gaa mod Nord, idet den strakte sig helt op til Edinburg. Nu havde jo rigtignok Britannien hørt til Romerriget, selv de nordlige Dele kunde altsaa nok siges at være i Besiddelse af Kulturmagnetisme. For at naa derover, maatte Anglerne i hvert Fald over Søen, og var de først paa Søen, var Vejen fri, der var ingen Folkestrøm bagved, som pressede sydpaa. Men Spørgsmaalet er netop det: hvorledes kom de overhovedet til Søen? Saa stærk var den nordbritiske Kulturmagnetisme dog næppe, at den virkede helt ind i Mellemtyskland. Den maatte faktisk være meget stærk for at naa saa langt, den maatte overvinde den direkte Kulturmagnetisme fra selve Rom, der drog Strømmen fra Elb-Egnene sydpaa og lokkede Langobarder, Saxer, Varner til Italien. Der er intet, der støtter en saadan An- 
tagelse. Kun de Stammer, der boede umiddelbart ved Kysten, havde fri Bane mod Nordvest, d. e. Havet, samtidig med, at de kunde følge Strømmen mod Syd over Land. ${ }^{1}$ )

1) Naturligvis beviser Saxernes og Herulernes Hjemvandringer, at man kunde byde Strømmen Trods, men de er dog som Hjemvandringer noget for sig, og foregaar desuden saa sent, at de falder næsten udenfor det egentlige Folkevandringstidsrum: Saxernes Hjemvandring er den sidste af den store Fulkevandrings Bevoegulser indenfor vor Folkeklasse, Herulernes er dan tredjesidste. Folkene var ved at falde til Ro i deres nye Boliger, Strommen mod Syd var ophort, saa at der fra den Side ikke kunde være nogen særlig Hindring for en Vaudring mod Nord.

Endnu kunde et Par Ord om de engelske ${ } J y d e r^{\prime \prime}$ være paa Plads. Hvem er det? Sproget ug den mulige Identitet med "Euthier" siger intet (se oventor Side $36 \mathrm{og} 43$ ). Den romerske Overlevering kender ingen Jyder, hverken i Britannien eller andensteds. Den kender jo overhoredet paa de senere Hovedstammers Plads ofte kun Smaastammer, f. Ex. netop i Jylland. $O \mathrm{~m}$ de enkelte Deltagere i Britanniens Erobring tier den helt, alle er "Saxer"; og naar den end ikke kender de mægtige Angier, hvor skulde den da kende de faatallige "Jyder" i Kent og paa Wight? Derimod omtales vidtløftigt de forberedende Vikingretog, der kom Romerne nærmere paa Livet; her maa man da sage "Jyderne". Navnet nytter det af ovennævnte Grunde ikke at søge; derimod byder vore "Jyder" folgende saglige Holdepunkter: 1) Traditionel Hjemstaun I)anmark. 2) Folgeskab med Saxerne; Kent og Wight ligger midt i saxisk Omraade. 3) Ledende Stilling; Forspring for Saxerne. Halvøen Kent og Wen Wight er Sydenglands naturlige Landgangsbroer. Overleveringen lader Kent være det første Landingssted, Wight-Strædet synes at rære det næste nye. (Wessex-Krøniken.) Et Folk, der opfylder Kravene, findes virkelig, det er det, som Romerne kaldte "Heruler ${ }^{4}$. 1) Deres Hjemstavn er I)anmark (se ovenfor Side 50). 2) De f(xlges med Saxerne. 3) De naa langt videre: Herulerne optræder fra Aar 289 og naa Gibraltar, Saxerne begynder først i det 4de Aarh. og naa kun den biskayiske Bugt. - Ligesom Narnet Jyder er ukendt i den romerske Overlevering, er Navnet Heruler ukendt i den hjemlige Over- 
Resultatet bliver: den geogratisk-historiske Overlevering fia I'tolemixus til Vilhelm af Mahmesbury henlægger enstemmig Anglernes Hjem til Landet nordenfor Elben; de fleste Kilder siger udtrykkelig Angel. De enkelte Modsigelser, d(r.r vell første Øjekast synes at foreligge, oploser sig ved nojere Eftersyn i Bekraftelse. Tilbage staar nu kun at betragte, hvorvilt ngsaa de kulturelle Kendgarminger vil bekrufte vort Resultat.

\section{Anglernes kulturelle Beroringer til Lands og til Vands.}

Ovenfor har jeg allerelle bersit den tyske Opfattelse med dens "ingreonske Kulturkreds ved Nord- og " (stersøen", ligeledes Grundtvigs Opfattelse, der hævdede Anglernes nære Slagtskith med Nordboerne modsat Tyskerne. Grundtvigs Bevisforelse staar den Dag idag som grundlieggende herhjemme, han var her som i saa Meget forud for sin Tid - og for vor Tid med, kan man gærne sige, thi naar (Grundtvigs (opfattelse staar saa uimodsagrt, er det narmest blot, fordi den modsatte Skole

levering, og det er da en granske naturlig Slutning, at de to Navne diekker hinanden. Ialfald har man Lov til at sporge, hvor Herulerne er blevne af? Dette navnkundig. Folk, der samtidig hærgede Vesteuropas Kyster til Gibraltar og 6 steuropas til Athen, og som var med til at styrte liom Aar 476, kan ikke vær" sunket i Jorden som et Lyn. Hyorfor har Herulerne ikke taget Land ligesim Angler og Saxer? Af Herulerne maa man netop forst og fremmest vente Landnam, da de jo nkommer f $s$ rst til Mulle“. Det ikke blot maa være tilladt, det er ligefrem nodvendigt at sogre dem under et andet Navn, og naar Historikerne har undladt at rejse Syorgsmaalet, har de gjort sig skyldige $\mathrm{i}$ en væsentlig Forsommelse. - Jeg mener altsaa, at Beda har Ret med sine engelske Jyder, og du't statter atter hans Angler fra Angel. 
ikke tager Hensyn til den. Her skal jeg blot kortelig fremheve nogle af de vigtigste Punkter.

1) Anglerne et Indlandsfolk eller et Kystfolk?

Ovenfor har vi betragtet det naturstridige $i$, at de thyringske Indlands-Angler skulde vare draget mod Strommen op til sisen for at naa Britanniens fjarne Nordegne. De kulturelle Forholl bekrafter kun vor Indvending, de viser os Angleme som det afgjorte Sofolk. Der er first deres Nerthus-Dyrkelse paa en $\emptyset$ i Oceanet, højst mierkelig for et Folk dybt inde i Mellemtyskland! Saa er der hele Anglernes gengratiske Forestillingskreds, saaledes som den er os hevaret i Vidsil. Dette Digt er en slags Katalogisering af Inatilens historisk-gengrafiske Viden i Eugland, og de hjemlige Folkestammer, som det nævner henholdsvis ikke nævner, giver os et gonlt liillede af Anglermes daglige nationale Omgangskreds, positivt og negativt. Nu viser det sig imidlertid, at Vidsid kender saagodtsom alle Stammer langs (Ssterswens, Vestechavets og Mellemlarenes hyster lige ud til vor Folkeklasses ylerste firansegne, men salagorltsom ikke ét Indlandsfolk, der ikke boer Dor om Dor med Angelsaxerne, end ikke de allervigtigste. Vidsid opregner saaledes nordiske Stammer holt op til Tremderne og sreerne og (Ostersofolk helt hen til Goterne og (repideme i Preussen, men det forbigaar i Tavshed saa vigtige og nore trske stammer som Alemanner, Hesser or Markomumer, nevner i det hele intet af Tysklands Indlandsfolk sondenfor Thyringerne.

Indenfor Kystfulkene er der atter ét bestemt, der lagger Beslag paa sarlig Interesse og Sympathi hos Anglerne. Man tienker uvilkaarlig: det maa være Anglernes 
Fæller ved Englandserobringen, Saxerne. Men man tager fejl, det er - Danerne. Det fremtræder tydeligst i første Del af Visid. Først nævnes Fyrster hos de mægtigste Folk: Hunner, Goter, Burgunder, Grækere. Dernæst opregnes. Hjemlandets mindre mægtige, men mere kendte Stammer og Fyrster, og endelig til allersidst Angler og Daner. De kommer last, not least, - tværtimod som Himmerigsmundfulden, det sees deraf, at alene disse to faa et Par særlige beskrivende Vers, mens alle de andre, ogsaa Stormagterne, affærdiges $\mathfrak{i}$ en Remse. I Slutningsversene fortælles der først om en ellers ukendt Danekonge Alvi (Alevih), at han var den ypperste af alle Mrnd, men, tilfyjes der, han overgik (eller overvandt) ikke Uffe. Derpaa nævnes, hvorledes Uffe værgede Angels Grænse ved Fiveldør, og tilsidst kommer atter nogle Linjer om Danerne, med Omtale af Hroars og Hrolvs Kampe mod Inggild og Hoddbrodd-Sønnerne. Paa den samme Interesse for Danerne og Forherligelse af dem er det navnkundige Beovulfskvad som bekendt et eneste stort Exempel. Man kan kort sagt ikke værge sig mod det altovervældende Indtryk, at Danerne staar som Anglernes Brødre. Men hvad er det da andet end det najagtige Supplement til den danske Overlevering, til vor Kongerækkes Ord, at Angel er Broder til Dan? Naar man ser den gamle, af Kritikerne anfægtede Beretning fra dette Synspunkt, falderder over den et nyt og forklarende Lys.

2) Digtning. Her finder vi stadig overvaldende Berøringer mellem England og Norden, især Danmark, kun forholdsvis svage mellem England og Tyskland. Nordisk Sagnstof vandrer fra Danmark til Anglerne, fra Angel til Danmark. Vi har ovenfor nævnt Anglerkongerne 
Viglek-Vermund - Uffe og Frøvin-Vig, der omtales i de danske Sagn, og Danekongerne Alvi, Hroar, Hrolv, der besynges af Anglerne. Foruden om de specielt østdanske Skjoldungkonger Helge, Hroar, Hrolv, handler Beovulfskvadet om Kong Huglek i "Geaternes" Land, d. v. s. vistnok Jylland (næppe Gotland), besynger hans Kampe mod Svenskerne og hans Fald mod Frankerne ved Rinen, der er en historisk kendt Begivenhed fra Aar 515. Baade Nordboer og Angelsaxer besynger Kong Høgne i Holmrygernes Land (Pommern), hans Datter Hilde og hendes Elsker Hedin, der kæmper om hende med den grumme Fader $\mathbf{i}$ det endeløse „Hjadninga-vig“, d. e. „HedinsMændenes Kamp"; Skuepladsen tænkes nær Hedinsø, nu Hiddensee ved Rygen. ") Om de mange fælles Myther se nedenfor. Fælles for Nordboer og Angelsaxer er ogsaa Navnet paa en særlig Sangerstand, den saakaldte "Thul“ (nordisk pulr, oldengelsk pyle). Overfor alt dette nordisk-engelske Fællesskab er det paaviselige tyskengelske Fælleskab kun tyndt. Af vigtige Sagnkredse er der nærmest kun den om Walther af Wasgenstein, og som Modstykke til den nordisk-engelske Sangertitel "Thul" staar en tilsvarede tysk-engelsk: „Scop". Niflunge- og Ermanrik-Sagnkredsene kom ganske vist fra Tyskland til England, men de kom ligesaafuldt til Norden, og de fleste af deres Personer tilhører fra først af slet ikke den tyske, men den gotiske, burgundiske og hunniske Historie.

3) Religion. Ogsaa her slutter Angelsaxerne sig ti Nordboerne, især Danerne og Sveerne, og fjærner sig fra

2) Dette Sagn vandrede i Middelalderen helt op til Øvre'ysskland l,vor det er kendt som Kudrun-Sagnet. 
Tyskerne. (Ovenfor er talt on de fælles mythiske Narne og Figurer Gaut, Svibilag, Hermod, Njorll (Forsete?), Ingve, Kong skjold mell Neget. Naturligvis maa man se bort fra 'Tyskernes spidstimlige Bortforklaringer, om at Nordboerne, hos hvem alt dette fortrinsvis er bevaret, "i Virkeligheden" stod udenfor, at Beorulfs "Daner" derfor ikke er Daner, fordi "Beorulfs Daner stod indenfor", samt alle de millest talt mærkelige Ringslutninger, sons deraf drages. Med Sikkerhed kan vi kun sige, at ialfald Tyskerne delvis stod udenfor. De havde Ermin og Isto til Nationalstamfedre, ${ }^{1}$ ) nedens Angelsaxerne og en Del af Nordboerne havde Ingve. Odlinstyrkelsen, der dreves saa ivrier af Angelsaxer, Langobarder og Nordboer, var alıleles ukendt i sydtyskland; deraf kommer det, at Hojtysk maatte oversætte det latinske "dies Mercurii“ ved "Mittwoch" d. e. "Midt-Cgedag" istedenfor "Onsdag". Hos sydtyskerne var den højeste Gud stadig Tyr, og en hel Stamme, Alemannerne, kaldte sig efter ham "Tyrsmænd" („Ziu-wari“). Tyr dyrkedes ogsaa under andre Navne. Af Frankerne kaldtes han pings, d. e. Thingeller Rets-Gud, deraf kommer det alm. tyske Navn for Tirsdag: Dienstag, egrentlig Dingstag, som stammer fra Franken. Bairerne kaldte ham Er, deraf baiersk Ertag = Tirsdag. Angelsaxerne har jo samme Navn for Tirsdag som vi (engelsk Tueslay), men forresten kendte de ogsaa Navnet Er, ialfald som Runenavn, og af saxeme paa Fastlandet dyrkedes Er ivrig. Fælles med Tyskerne havde Angelsaxerne endvidere en Foraarsgudinde "Eastre" $=$ tysk

1) Jfr. Tacitus Kap. 2, Plinius Kap. 96; Frmin er Stamfader for Stammerne $\mathrm{i}$ det indre Tyskland, Isto for Stammerne ved Rinen. 
"Ostern“, Paaske, men det er ogsaa omtrent alt, hrad der lader sig paavise af religiøst Fællesskab mellem Angelsaxer og Tyskere.

4) Ret. Ogsaa her skal Angelsaxerne ligesom Langobarderne afgjort staa Nordboerne nærmest, men herom skal jeg ikke kunne udtale nogen egen Mening. (Jfr. et for kort Tid siden udkommet Skrift af ()verretssagf ırer Kjæer: (Om Langohardernes Nationalitet, Aarhus 1898.).

5) Bebyggelse og Agerbrug. Fjendommeligt nok synes Angelsaxerne her at slutte sig nojere til Tyskerme end til Nordboerne. I England hersker fra ganmel Tid det tyske Trevangsskifte (Sommersad, Vintersied, Brak), som synes ukendt $\mathrm{i}$ det gamle Jylland (Sach, S. 132). Kun sjaldnere optræeler i Kingland det gamle Agerbrug med én Ager ("wilde Feldgraswirths'haft"). De engelske Stednavne er stulte efter ganske samme Type som rle tyske: Jfr. Bro: eng. Bridge, tysk Brücke; Groft: e. t. Ielf; Landingsplads: eng. Hithe, tysk Hude; "Vad" (Vadested) : e. t. Ford; Kar: e. t. Brook; Hurst. En Del af de Stednavne, som regnes for tysk-engelske, genfindes dog ogsaa, omend kun enkeltris, i Norden. Saaledes engelsk Field, tysk Feld (Mark) i (tisselfeld paa Sjæelland (14. Aarh.), Nutrefelle paa Als (1231) og i talrige Forstavelser: Feldborrg, Fjellerup, Felding (jfr. engelsk Fielding) etc. Engelsk Lea, tysk Loh ((Oldesloh), e. t. Ho (Ivanhoe, Itzehoe), begge $=$ Skov, genfindes i Lohals verl Limfjorden, $O(p)$ slo ved Kristiania, Ho ved Varde. $\left.{ }^{1}\right)$ - Saa er der endelig nogle ganske vist faa, men ragtige nordisk-engelske ()verensstemmelser: engelsk Wood, nordisk Ved (Sundered) =

1) Eng. Bottle, t. Büttel er = d. Bol (Medd. fra Prof. H. Msller.) 
Skov; engelsk Tun, „indhegnet Plads“ (tysk Zaun = Hegn), engelsk Yard, nordisk Gard $=$ tysk Hof (tysk Garten = Have). - Det er ikke mange, men de vejer ikke saa lidt. De mange tysk-engelske Overensstemmelser vejer ret besét ikke saa meget, thi det er mest Navne paa Skov, Kær, Vande, kort sagt Steder i den frie Natur, som ikke hentyder til nogen bestemt Bebyggelse. Da det angelsaxiske Sprog stod nærmest ved Tysk, ogsaa i Ordforraad, er det saa at sige en Selvfølge, at dets Stednavne maa have et Overskud af tysk-engelske Fællesord. Hvad det her imidlertid gælder om, er ikke FællesOrd, men Fælles-Begreber, fælles Bebyggelsesformer. $\mathrm{Og}$ af saadanne findes der blandt de af Sach anforte Navne egentlig intet tydeligt. - Derimod byder det nordiskengelske Fællesforraad hele to, nemlig: Tun og Gaard. ${ }^{1}$ ) Tun spiller som bekendt en aldeles overvældende Rolle i de engelske Navne (jfr. Washington, Hamilton, Wellington, Newton), medens det i Norden kun har en beskednere Udbredelse (Tune Herred paa Sjælland, Saltuna paa Bornholm, Eskilstuna, Sigtuna i Sverrig etc.). Altsaa bestaar der dog et ikke uvæsentligt Fællesskab mellem Angelsaxer og Nordboer ogsaa i Bebyggelse. ${ }^{2}$ )

Vort Hovedresultat bliver da dette: Bedas og den danske Kongerækkes Ord bør staa ved Magt. Anglerne boede i Angel. Angel var Broder til Dan. Anglernes

1) Efter P. Lauridsen (Aarb. f. dansk. Kult. 1899. S. 83) tilføjer jeg: Løse (Græsgang) = angelsax. læsu.

2) Jeg kan her ikke indlade mig paa de mærkelige Lev-Navne, som hersker i hele Danmark, optræder enkeltvis i England og talrigt i et snævert Strag i Mellemtyskland (dansk Indvandring? Sammesteds enkc'lte By: Barby, 2 Brumby, Elbey, alle ved Magdeburg). 
Samkvem og kulturelle Forbindelser peger nordpaa mere end sydpaa; jeg kunde fristes til at sige: de stod i lige saa nær Berøring med de fjærneste nordiske Stammer, Sveerne 0. a., som med deres nære Naboer, de senere tyske Stammer, Hesser, Alemanner, Angrivarjer, og hvad de nu allesammen hed. Det lyder maaske paradoxalt, at Anglerne skulde have staaet det fjærne saa nær og det nære saa fjærnt. Men naar det forundrer os saameget, er det atter, fordi det er en af disse Ting, hvor vi sér paa Fortiden med Nutidsøjne og dømmer den derefter. Yor Tid er Dampens Tid, hvor en Afstand er en Afstand, hvad enten der ligger Vand eller Alper imellem - fordi Dampen ingen Skranker kender, - men hvor Fordelen, naar man endelig skal tale om den, er paa Landrejens Side; det er ikke for ingen Ting, at Ordet Isolation kommer af en $\emptyset$ (italiensk isola). — I Fortiden var det anderledes. Da var Landvejen ingen Landevej, nej, vore Forfædres Landevej og Kongevej, eller for at tale moderne, deres magelige Chaussé til Befordring pr. Damp og Elektricitet, - det var Havet. Før hundrede Mile til Vands end ti til Lands. Den Gang var et "land ikke isoleret, tværtimod, thi den Gang var det Sandhed med Havet som den "Grænse, der skiller ej". Derfor var det, at Dan blev Angels Broder, derfor var det, at overhovedet Kystlændingene følte sig som Brødre, som Srmner af den fælles Nationalstamfader Ingve, i Modsætning til Indlændingene, Ermins og Istos Sønner.

Efter Folkevandringen, alt eftersom Folkebevægelserne afgrerede, døde det raske Sømandsliv efterhaanden hen. Efterkommerne af de angelsaxiske Vikinger, der erobrede Britannien, kunde knap nok stille et Skib mod 
de nordiske Vikinger, og Efterkommerne af de nordiske Vikinger, der erobrede Britannien, kunde knap nok stille et Skib mod de vendiske og esniske Vikinger. Under saadanne Forhold svandt naturligvis enhver levende Forbindelse mellem England og Norden; „Isolationen" indtraalte. $O g$ i selve Engliendernes Stamland ophorte ogsaa den gamle Folkeforlindelse, men paa en anclen Maade, nemlig derverl, at Angrelsaxernes Rester helt blev opslugte af Nabofolkene: fra Nord overskylledes deres Omraade af Danskerne (i simderjylland), fra sonden af Tyskerne (i Hannover og Holsten). I Bergyndelsen var det, som vi saa, Angler og Saxer, der tringte erobrende frem mod Syd og Vest paa tysk (Omraade mod Thyringer, Bruchtrer etc. Men senere vendte IBladet sig; Frankerne optog en energisk Modbeviogelse mod deres Medhejlere on Herredimmet i Tyskland, og efter en haardnakket Frihedskamp maatte saxerne boje sig. Karl den Store satte Kronen paa Varket ved sin systematiske Blordaabsog Masseomflytningspolitik.

Itlet nu Daner og Franker fra hver sin side overskyllede anglisk og saxisk Mrellemomraade og tornede sammen red Ejileren, opstod der for firste og nosten eneste (rang indenfor vor Sprogklasse en virkelig Sproggranse. Det vil sige et direkte Møodepunkt mellem to hinanden fjærnerestaaende Dialekter. - Tidligere var der, som ovenfor bemarket ingen saadan, saalidt som der existerede Nationalkegreber som Nordisk og Tysk; sproglig fjærnere og geografisk fjæxnere var dengang ét og det samme. Nordens og Tysklands Dialekter havde ligget i Nord og Syd som Regubuens Blaat og Rolt, skilte og forbundne ved Mellemfarver, der fortonede sig 
jarnt og umærkelig ud til begge Sider, fra (Xansk til Jysk, fra Jysk til Anglisk, fra Anglisk til Saxisk, fra Saxisk til Frisisk, Frankisk og Thyringsk. Ingen kunde se, hvor det ene horte op, og det andet begyndte. Nu 1)aa éngang forsvandt de vage MIellemtoner, det Blaa og det liøde sk $\bullet d$ imod hinanden, saa Gnisterne rog. Fra nu af har Danmark et dansk sprog, Tyskland et tysk, og de angliske og saxiske Mellemdialekter er henloldsvis fordanskede og fortyskele. - Men England er "isoleret“; he'r bliver Anglisk og Saxisk til Angelsaxisk, og det er som Folge af Isolationen hverken dausk eller tysk, men engelsk.

Efterskrift: Siptningen Side 25 "I want a scissors" er ikke $\mathrm{H}$ (ijengelsk, - det hedder "I want a pair of scissurs“, men den hures faktisk i Folkernunde. 